\title{
12,000-Year-Long Record of 10 to 13 Paleoearthquakes on the Yammoûneh Fault, Levant Fault System, Lebanon
}

\author{
by Mathieu Daëron, Yann Klinger, Paul Tapponnier, Ata Elias, Eric Jacques, and Alexandre Sursock
}

\begin{abstract}
We present results of the first paleoseismic study of the Yammoûneh fault, the main on-land segment of the Levant fault system within the Lebanese restraining bend. A trench was excavated in the Yammoûneh paleolake, where the fault cuts through finely laminated sequences of marls and clays. First-order variations throughout this outstanding stratigraphic record appear to reflect climate change at centennial and millennial scales. The lake beds are offset and deformed in a 2-mwide zone coinciding with the mapped fault trace. Ten to thirteen events are identified, extending back more than $\sim 12 \mathrm{kyr}$. Reliable age bounds on seven of these events constrain the mean seismic return time to $1127 \pm 135 \mathrm{yr}$ between $\sim 12 \mathrm{ka}$ and $\sim 6.4 \mathrm{ka}$, implying that this fault slips in infrequent but large $(M \sim 7.5)$ earthquakes. Our results also provide conclusive evidence that the latest event at this site was the great A.D. 1202 historical earthquake, and suggest that the Yammoûneh fault might have been the source of a less well-known event circa A.D. 350. These findings, combined with previous paleoseismic data from the Zebadani valley, imply that the parallel faults bounding the Beqaa release strain in events with comparable recurrence intervals but significantly different magnitudes. Our results contribute to document the clustering of large events on the Levant fault into centennial episodes, such as that during the eleventh through twelfth centuries, separated by millennial periods of quiescence, and raise the possibility of a $M>7$ event occurring on the Yammoûneh fault in the coming century. Such a scenario should be taken into account in regional seismic-hazard assessments and planned for accordingly.
\end{abstract}

\section{Introduction}

Understanding fault behavior over the span of many seismic cycles is key to answering several unresolved questions. How irregularly do earthquakes occur? What governs the time clustering of large events on a fault system? How do faults interact mechanically at centennial and millennial timescales? How should the timing, magnitudes, and sources of past earthquakes be taken into account to assess future events? Documenting long-term fault activity is not straightforward, however, due to the requirement of exhaustive historical and/or paleoseismological data sets. Currently, there are relatively few examples of long time series of events on a fault segment (e.g., Sieh, 1984; Jing et al., 2006; Biasi et al., 2002; Weldon et al., 2004) or of well-documented time/ space series of historical earthquakes along strike-slip faults (e.g., Barka and Kadinsky-Cade, 1988; Hubert-Ferrari et al., 2000; Stein et al., 1997).

The Levant fault system (LFS), along the eastern coast of the Mediterranean, offers a good opportunity for such work, thanks to a very long historic record spanning more than two millennia. Recently, several archeo- and paleoseismic studies have offered evidence linking historical earth- quakes to specific fault segments (Ellenblum et al., 1998; Klinger et al., 2000b; Gomez et al., 2003; Meghraoui et al., 2003; Marco et al., 2005; Daëron et al., 2005). Here we present new paleoseismic data that provide a particularly long record of earthquakes on the main "Lebanese" segment of the LFS. See Table 1 for the notations used in this study.

\section{Seismotectonic Setting}

\section{The Levant Fault System}

The northward motion of Arabia away from Africa, corresponding to the opening of the Red Sea and Gulf of Aden (e.g., McKenzie et al., 1970; Courtillot et al., 1987), started in the Early Miocene (20-25 Ma) (e.g., Manighetti et al., 1998; Bosworth et al., 2005). Along the Levantine coast of the eastern Mediterranean, this motion is taken up by a 1000$\mathrm{km}$-long transform fault, the Levant fault system (or "Dead Sea transform"), which connects the Red Sea ridge to the southwest segment of the East Anatolian fault system (Fig. 1a). The Quaternary rate of slip on the LFS is poorly 
Table 1

Notations Used in This Study

\begin{aligned} & \multicolumn{3}{c}{ Notations Used in This Study } \\ & \hline L Stratigraphic layers \\ & K Samples from wall K \\ & G Samples from wall G \\ & F Fault breaks observed in the trenches \\ & C Bayonet-shaped cracks (see text) \\ & S Paleoseismic events \\ & ?S Ambiguous paleoseismic events \\ & \hline\end{aligned}

constrained, with current estimates ranging from 2 to $8 \mathrm{~mm} /$ yr (Chu and Gordon, 1998; Klinger et al., 2000a; Niemi et al., 2001; McClusky et al., 2003; Meghraoui et al., 2003; Gomez et al., 2003; Wdowinski et al., 2004; Daëron et al., 2004; Daëron, 2005; Mahmoud et al., 2005).

A rich body of historical sources and archaeological data, extending back more than 26 centuries, testifies to the occurrence of numerous strong $(M>7)$, destructive earthquakes along this plate boundary (e.g., Poirier and Taher, 1980; Abou Karaki, 1987; Ben-Menahem, 1991; Ambraseys et al., 1994; Guidoboni et al., 1994; Guidoboni and Comastri, 2005). Nevertheless, there are few constraints on the return times of such events or on their possible time clustering at the scale of several centuries. The magnitudes of these large historical earthquakes contrast sharply with the relative quiescence of the fault system during most of the instrumental period. Between A.D. 1837 and 1995, the strongest event on the Levant fault was the $M \sim 6.2$ Jericho earthquake (e.g., Plassard, 1956; Ben-Menahem and Aboodi, 1981; Avni et al., 2002). In 1995, the southernmost section of the LFS produced a $M_{\mathrm{W}} \sim 7.3$ earthquake in the Gulf of Aqaba (e.g., Klinger et al., 1999; Al-Tarazi, 2000; Hofstetter, 2003). This event calls attention again to the long-term potential for large earthquakes along the plate boundary, highlighting the risk of other strong events during the coming decades in this densely populated region. To address this scientific and practical issue requires extending and refining the historical record using paleoseismic data from various segments of the fault system. We discuss next the first such study of the Yammoûneh fault, within the Lebanese restraining bend.
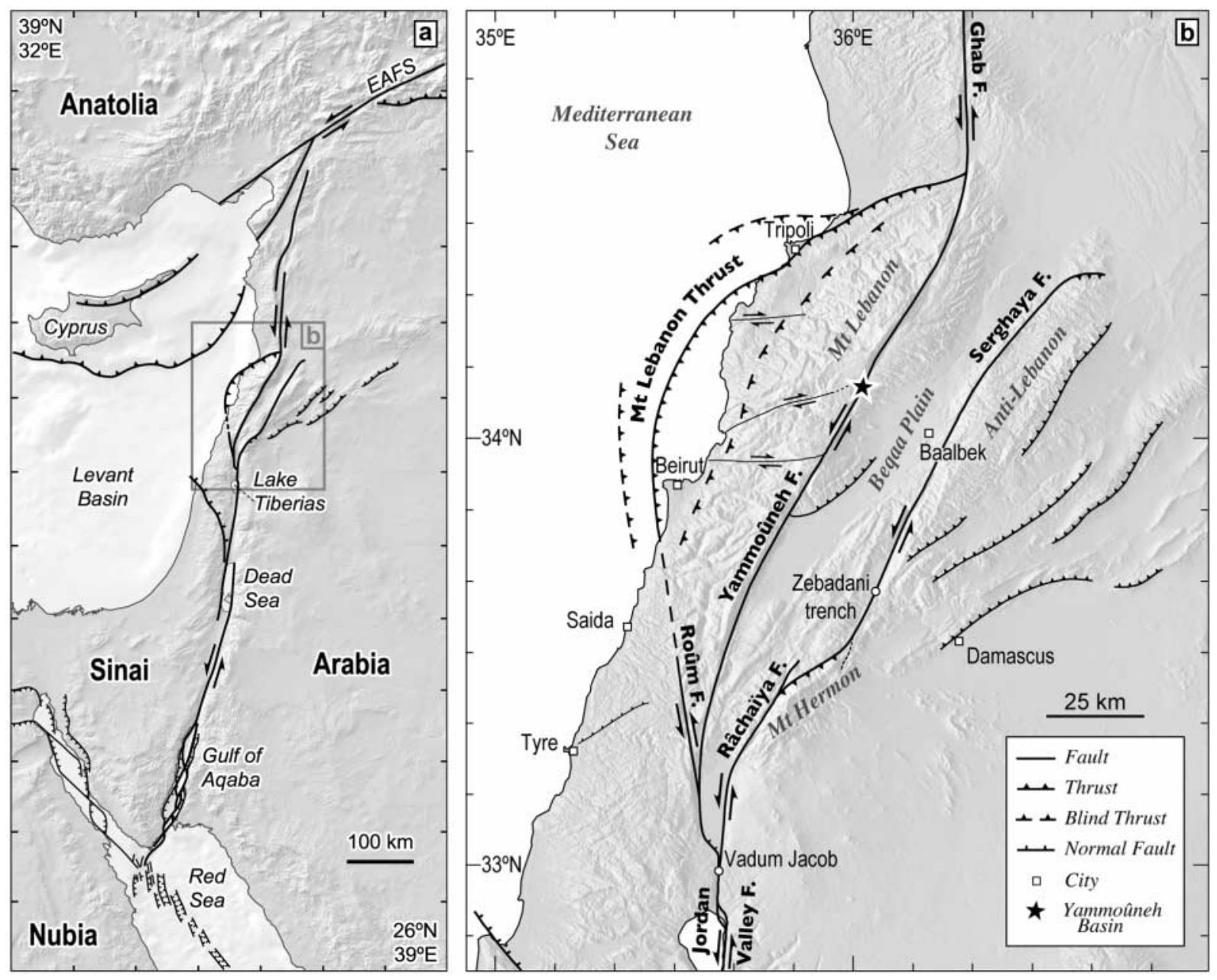

Figure 1. Regional tectonic setting. (a) Map of the Levant fault system. (b) Active faults of the Lebanese restraining bend. 


\section{The Lebanese Restraining Bend}

Along most of its length, especially south of Lake Tiberias, the surface trace of the Levant fault is composed of en-echelon strike-slip segments separated by large pullaparts or smaller push-ups (Garfunkel et al., 1981). In the area of Lebanon, however, the Levant fault's trace curves to the right, forming the 160-km-long "Lebanese" restraining bend (LRB). The resulting strike-perpendicular strain has long been held responsible for crustal shortening and uplift (e.g., Quennell, 1959; Freund et al., 1970). Within the restraining bend, deformation is partitioned between northnortheast-trending thrusts and strike-slip faults, which bound areas of active mountain building in the Lebanon and AntiLebanon ranges (Fig. 1b) (Daëron et al., 2004; Carton, 2005; Daëron, 2005; Elias, 2006). The Yammoûneh fault appears to be the most active of these strike-slip segments. It connects the Jordan Valley fault, in the south, to the northern Levant fault, and forms the sharp topographic and structural eastern boundary of Mount Lebanon. The slip rate on this fault was constrained to be 3.8-6.4 mm/yr using cosmogenic dating of offset alluvial fans (Daëron et al., 2004), accounting for much of the Levant fault's overall slip at this latitude.

Historical studies of earthquakes in the area of the LRB (e.g., figure 5 in Ben-Menahem, 1991) have in general assumed that the Yammoûneh fault was the source of the three known $M>7$ events of the past 15 centuries, in A.D. 551, 1202, and November 1759 (Table 2). If this were the case, the historical mean return time of strong earthquakes on this fault would be about six centuries, suggesting that we are currently halfway through the seismic cycle. Because the active fault strands of the LRB are subparallel and closely spaced, however, discriminating between potential fault sources requires combining historical data with direct geomorphic and paleoseismic evidence (Gomez et al., 2003; Daëron et al., 2005). Here we describe and discuss new paleoseismic data from the Yammoûneh basin, along the eponymous Yammoûneh fault (Fig. 1b).

\section{Trench Setting: The Yammoûneh Basin}

The Yammoûneh basin is located $1400 \mathrm{~m}$ above sea level, on the eastern flank of Mount Lebanon (Figs. 1b and $2 \mathrm{a})$. It is the largest $(1.5 \times 6 \mathrm{~km})$ of several fault-controlled troughs that disrupt the linearity of the Yammoûneh fault. The basin's long axis strikes north-northeast, roughly parallel to the fault's trace. It is inset between thick subtabular sequences of karstified Cenomanian limestone (Fig. 2c). To the west, the Jabal Mnaïtra karstic plateau rises abruptly to $2100 \mathrm{~m}$ (Fig. 2b). To the east, the basin is separated from the Beqaa by gently sloping hills (Jabal el-Qalaa, 1500 m).

North and south of the basin, we mapped the trace of the Yammoûneh fault in detail. To the south, it follows the western flank of a north-trending limestone ridge, merging with the basin's southeast margin (Fig. 3a). To the north, Dubertrer (1975, Baalbek sheet) mapped the fault as following the Aïnata river (see location in Fig. 4a). From our own

Table 2

Summary of the Effects of the Strongest Historical Earthquakes of the Lebanese Restraining Bend

\begin{tabular}{|c|c|}
\hline Date and Main References & Known Macroseismic Effects \\
\hline $\begin{array}{l}\text { Plassard (1968) } \\
\text { Darawcheh et al. (2000) } \\
\text { Guidoboni et al. (1994) }\end{array}$ & $\begin{array}{l}\text { Shaking and a powerful sea wave caused severe damage all along the Phoenician coast (destruction of Berytus, } \\
\text { Tripolis, Sidon, Byblus, Botrys, Tyre, and } 101 \text { towns in that area), with many casualties. In Berytus (Beirut), which } \\
\text { suffered the worst (" } 30,000 " \text { casualties, widespread collapse of buildings), the sea retreated two miles before returning. } \\
\text { The coast north of Laodicea and south of Tyre appears to have been spared comparatively. This event was felt strongly } \\
\text { in Antioch and Alexandria, and felt in Phoenicia, Syria, Palestine, Arabia, and Mesopotamia. Estimated magnitudes: } \\
M_{\mathrm{L}} \sim 7.8 \text { (Ben-Menahem, 1991), } M_{\mathrm{S}} \sim 7.2 \text { (Darawcheh } \text { et al., 2000). }\end{array}$ \\
\hline $\begin{array}{l}\text { Ambraseys and Melville } \\
\text { (1988) }\end{array}$ & $\begin{array}{l}\text { Heavy destruction in western Syria and the Crusader states. At the Jupiter temple of Baalbek (Beqaa), } 31 \text { of } 40 \\
\text { monumental columns were toppled. The cities of Nablus, Acre, Safed, Tyre, Tripoli, and Hamah, among others, } \\
\text { suffered severe damage. Rock falls in Mount Lebanon killed } \sim 200 \text { people. Shaking was felt throughout the } \\
\text { Mediterranean and Middle East, up to } 1200 \mathrm{~km} \text { away, and aftershocks were reported for at least } 4 \text { days in Hamah, } \\
\text { Damascus, and Cairo. There is archaeological and paleoseismic evidence for } 1.6 \mathrm{~m} \text { of left-lateral offset recorded by the } \\
\text { walls of the Vadum Jacob castle, just north of Lake Tiberias (Ellenblum et al., 1998). Estimated magnitude: } M_{\mathrm{S}} \sim 7.6 \\
\text { (Ambraseys and Melville, 1988). }\end{array}$ \\
\hline $\begin{array}{l}\text { A.D. } 1759 \text { (25 November) } \\
\text { Ambraseys and Barazangi } \\
\text { (1989) }\end{array}$ & $\begin{array}{l}\text { Near-complete destruction of the villages in a } 120-\mathrm{km} \text {-long narrow zone extending north-northeast from the Beqaa } \\
\text { plain to the upper reaches of the Orontes. Safed, Hasbaya, Serghaya, and Baalbek were almost completely destroyed, } \\
\text { and heavy damage extended to Ras-Baalbek. At the Jupiter temple of Baalbek (Beqaa), } 3 \text { of the } 9 \text { remaining columns } \\
\text { were toppled. Ambraseys and Barazangi (1989) mention reports of ground ruptures more than } 100 \mathrm{~km} \mathrm{long} \mathrm{in} \mathrm{the} \\
\text { Beqaa. The earthquake caused heavy but repairable damage in Damascus, and was strongly felt in Antioch, Aleppo, } \\
\text { Ladhikiya. Gaza, Al-Arish, and Tarba. A seismic wave was reported as far south as the Nile delta. Estimated } \\
\text { magnitude: } M_{\mathrm{S}} \sim 7.4 \text { (Ambraseys and Barazangi, 1989). This event was preceded, on } 30 \text { October, by a } M_{\mathrm{S}} \sim 6.6 \\
\text { earthquake to the south of it. }\end{array}$ \\
\hline
\end{tabular}

Based on reassessed historical sources, geomorphic observations, and paleoseismic evidence discussed further in this study, we previously argued that the sources of the 1202 and November 1759 events were the Yammoûneh and Serghaya faults, respectively (Daëron et al., 2005). 

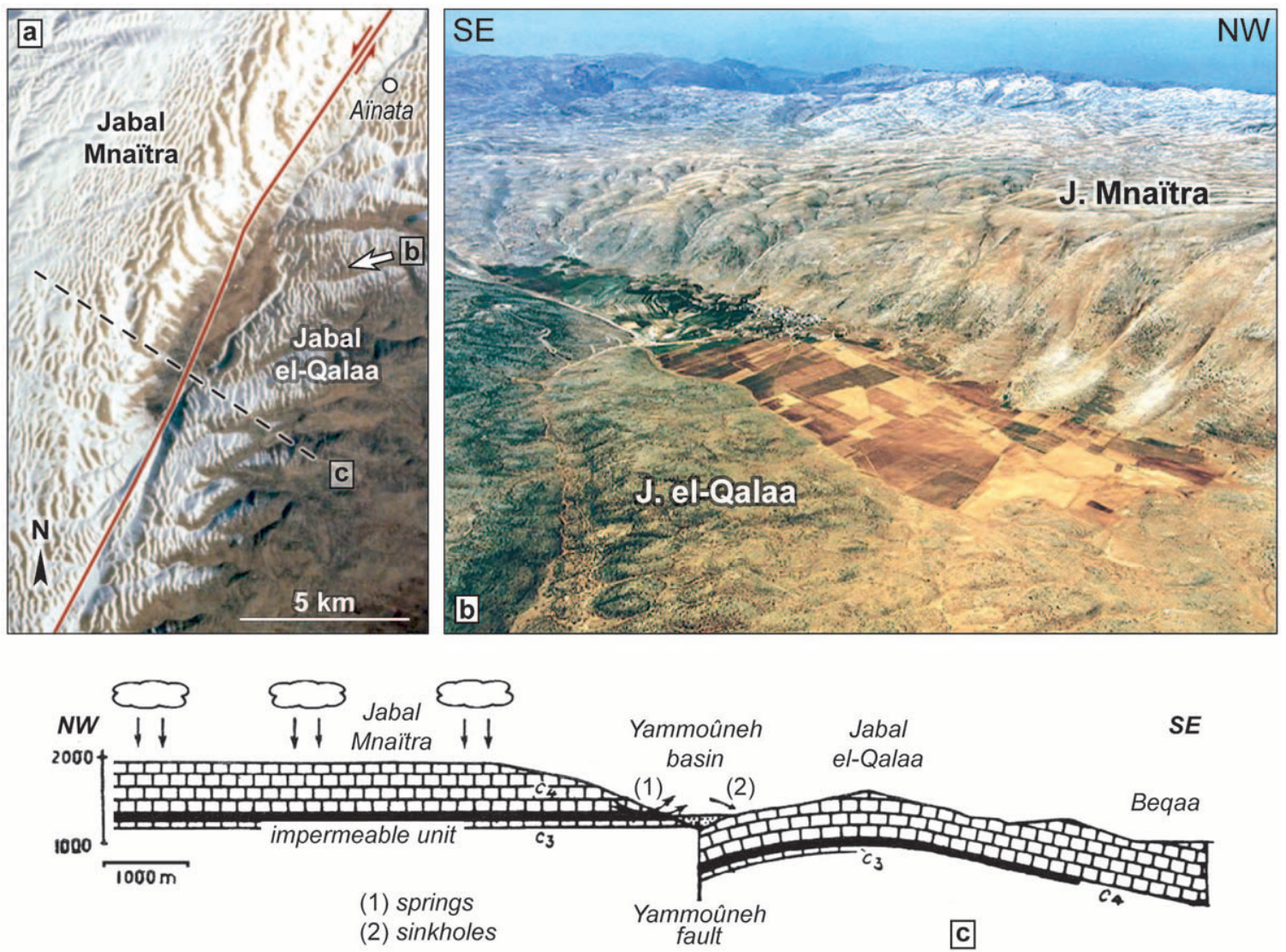

Figure 2. Overview of the Yammoûneh basin. (a) Satellite image of the basin, between the Mnaïtra plateau and the Qalaa hills. The white arrow indicates the viewpoint of (b), and the red line marks the active trace of the Yammouneh fault. The location of the town of Aïnata is marked by a white circle. (b) West-southwest-looking, oblique aerial photograph of the basin. (c) Simplified geological cross section, modified from Dubertret (1975, Baalbek sheet).

observations, however, the active trace lies above and west of the Aïnata river bed, cutting across the limestone flank of the Jabal Mnaïtra (Fig. 3b). In map view, the basin thus clearly lies within a left stepover of the fault (Fig. 2a). Along with the basin's rhomboidal shape, this implies that it originally formed as a pull-apart, as proposed by Garfunkel $e t$ al. (1981).

The study of high resolution satellite images and 50year-old air photographs, however, shows that there is now a direct connection between the northern and southern faults, cross-cutting through the basin sedimentary infill. Within the basin, the surface trace of this connection is marked by subtle soil color and vegetation changes, and by deviated or offset gullies. Rather than continuing along the flank of Jabal Mnaïtra, the northern fault segment bends to the south as it approaches the basin. Before entering the basin's flat floor, it cuts and offsets two alluvial fans by a few tens of meters (Daëron et al., 2004). Our mapping of the fault across the basin's southern half (Fig. 4) is consistent with resistivity data, interpreted by Besançon (1968) as evidence that the fault cuts through the basin and vertically offsets the underlying bedrock. The available observations thus imply that, although the basin initially formed as a pull-apart, this releasing stepover evolved toward a simpler, smoother geometry, with a new fault cutting across the basin. Such a geometry has often been observed along other strike-slip faults (e.g., Deng et al., 1986; Pelzer et al., 1989; Armijo et al., 2005). On both sides of the basin, where young, clastic sediments abut the surrounding limestone units, we find no evidence of recent strike-slip motion, which suggests that all or most of the horizontal slip on the Yammoûneh fault is taken up by the midbasin strand.

The basin's floor comprises two types of Quaternary sediments (Fig. 2b). In its larger, northern part, limestone fanglomerates and red-brown clays (Fig. 4a), mostly fed by the Aïnata river, overlie the Cenomanian limestone bedrock. They are locally covered by debris flow and colluvial fans at the base of the steep slope of Jabal Mnaitra. In the southern third of the basin, a $700 \times 1800 \mathrm{~m}$ patch of whitish deposits contrasts with the elastic alluvium. The deposits are 

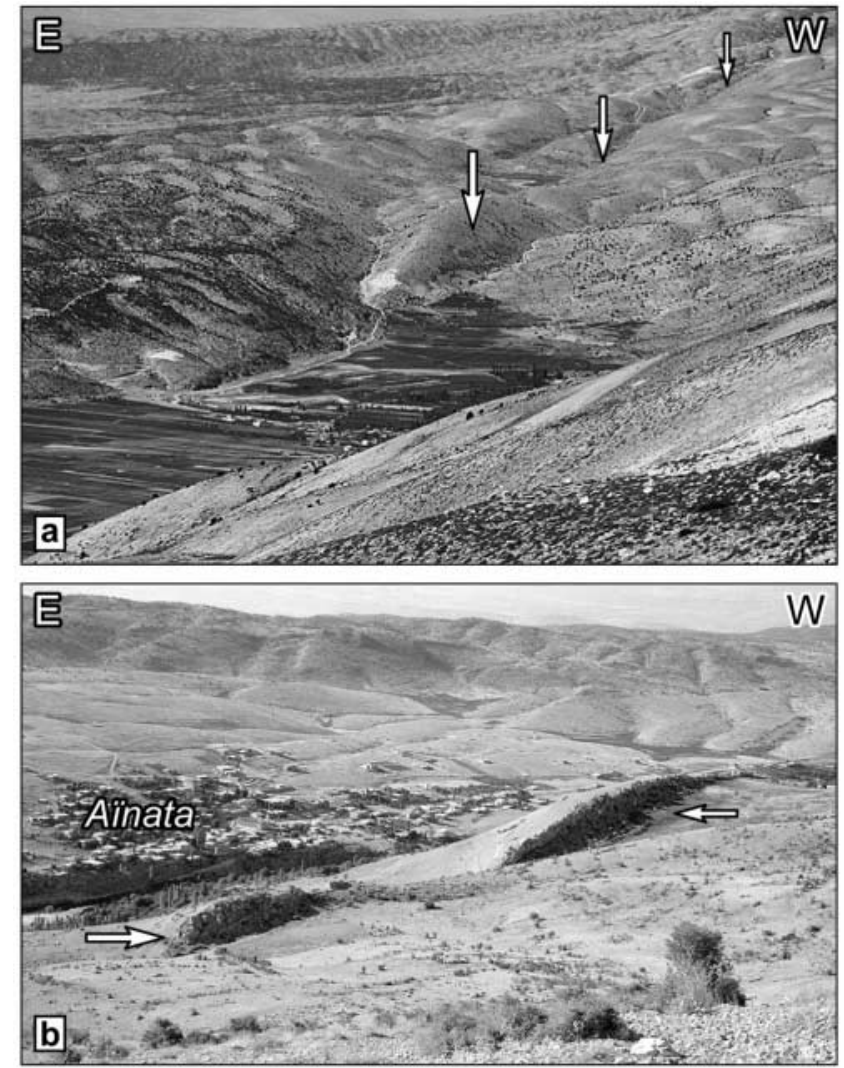

Figure 3. Active fault trace south and north from the Yammoûneh basin. (a) south-looking view of the paleolake (darker infill area). The active trace of the fault (white arrows) runs along the west flank of a limestone ridge aligned with the east margin of the basin. (b) south-looking view of the Yammoûneh fault above the village of Aïnata. Cumulative slip has formed several asymmetric, scarp-bounded, limestone shutter ridges (white arrows). Distance between the arrows is $400 \mathrm{~m}$.

calcareous lacustrine marls, containing abundant freshwater gastropod shells.

The white marls accumulated in the lowest part of the basin because of its peculiar hydrographic setting. The Mnaïtra plateau remains completely snow covered almost 4 months a year (Service météorologique du Liban, 1971). Beneath the plateau, subterranean karstic networks collect melt-water, feeding a dozen springs along the western edge of the basin. In times of slow discharge, the water follows sinuous channels that drain into karstic sinkholes near the opposite eastern border. Since at least Roman times, in seasons of stronger discharge (March to June) due to melting of the snow atop the plateau, the water filled a lake that used to persist for a few months (Besançon, 1968). (Etymologically, "Yammoûneh" can be translated as "little sea" in Arabic, which might refer to the lake.) This seasonal lake was drained in the early 1930s following construction of an underground duct designed to collect water from the main
Yammoûneh sinkhole (el-Baloua, cf. Fig. 4b) to irrigate the Beqaa plain. Today, the former area of the paleolake corresponds to the most fertile, cultivated part of Yammoûneh basin (Fig. 4b).

The distinctive tectonic and hydrographic characteristics of the basin offer an excellent opportunity to study the long-term seismic record of the Yammoûneh fault. The tectonic setting, in which the active fault trace cuts through finely stratified lake beds, provides good conditions for trenching. This was confirmed by a 5-m-deep exploratory pit near el-Baloua (Fig. 4b), away from the fault, which exposed a thinly laminated sequence of marls and clays, with multiple peat layers (Fig. 5a). Finally, in this lacustrine setting, excavating was greatly facilitated by the recent lowering of the water table following the drying-up of the lake.

We trenched across the inferred fault trace, $\sim 80 \mathrm{~m}$ west of the eastern paleoshoreline, on the bank of a semipermanent stream, the Nahr el-Kazzâb (Fig. 4b). To test our mapping of the fault trace, we started excavating well west of the expected intersection between the fault and the Kazzâb channel. The resulting "Kazzâb" trench was $4 \mathrm{~m}$ wide, $\sim 75 \mathrm{~m}$ long, and 3-5 $\mathrm{m}$ deep. The subhorizontal lacustrine marls and clays thus exposed were found to be undisturbed except in one 2-m-wide zone at the inferred location of the fault. Plate $1^{1}$ [unbound insert to this issue] and Figure 7 show the central $8 \mathrm{~m}$ of the southern wall of the Kazzâb trench ("wall K"). To further constrain the latest recorded events, a secondary, shallower trench was later excavated, parallel to wall $\mathrm{K}$ and $\sim 1 \mathrm{~m}$ south of it ("wall G," Fig. 8).

\section{Stratigraphy}

\section{Main Stratigraphic Sequences}

In keeping with the surface facies of the basin infill, the trench sediments comprise two distinct units: compact calcareous marls overlying red-brown clays. The distinctive clay/marl transition (Fig. 5b), about 3-3.5 m below the surface, is remarkably horizontal away from the fault zone, as are most of the exposed layers. Although shallow dips perpendicular to the trench would be difficult to observe, one would expect the lake beds to dip west, if at all, away from the eastern paleoshoreline. We observe no such dips in the trench, and conclude that most beds were deposited horizontally in the shallow-water environment.

The lacustrine sediments have a rather homogeneous texture, apart from first-order variations such as the clay/ marl transition. The various units' colors, by contrast, vary

\footnotetext{
${ }^{1}$ Plate 1: North-facing wall of the Kazzâb trench, across the left-lateral Yammoûneh fault ("wall K"). Calcareous, whitish to light brown, lacustrine marl beds overlie red-brown clays of likely palustrine origin. The generally continuous units exposed here have recorded 10 to 13 events, which resulted in a 2-m-wide zone of splaying fault breaks and distributed deformation. The log of this wall is shown in Figure 7. The white star marks the location of the similar symbols in Figures 7 and 9 a,b.
} 

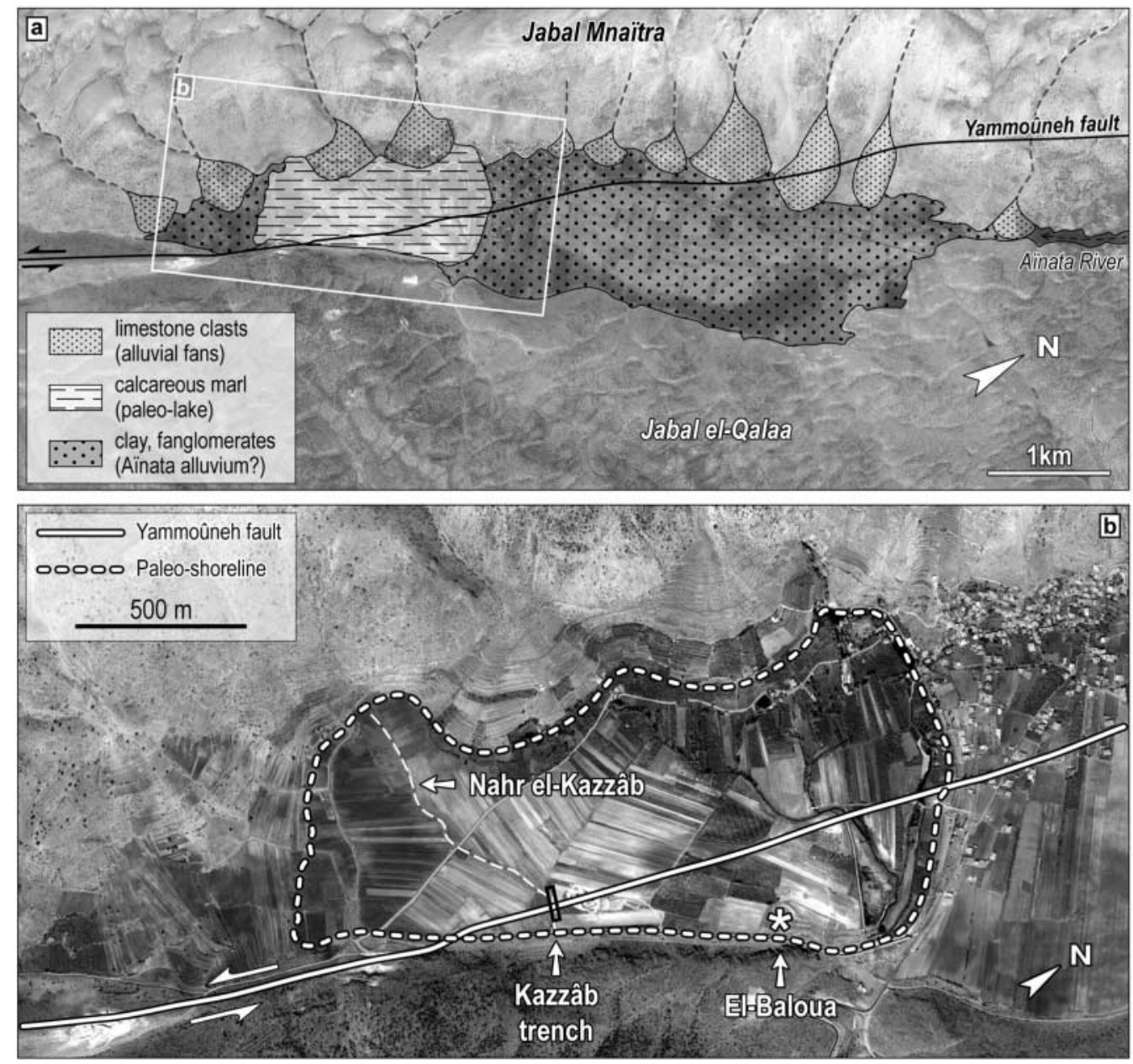

Figure 4. Maps of the Yammoûneh basin. (a) Quaternary geology of the basin. (b) The trench (black rectangle) parallels the channel of the Nahr el-Kazzâb stream (thin dashed line) where it crosses the fault (solid white line). A white star marks the location of the main karstic sinkhole (el-Baloua), where the exploratory pit of Figure 5 a was excavated.

distinctively from one layer to another. These color transitions generally occur abruptly (in depth), which likely reflect correspondingly abrupt (in time) sedimentary changes, and/ or short-term perturbations of the sedimentary regime allowing for slight alteration of the top-most deposits. In this setting, most individual layers can be followed over long distances (at least tens of meters). We characterized and correlated the units based on sequence patterns of color and thickness (e.g., "shell-rich, thick, white marl overlying thin, brown marl") (Figs. 6, 7, and 8). The main sequences are described briefly on the following. Table 3 provides a layerby-layer description of units.

The upper $3.7 \mathrm{~m}$ of the exposed stratigraphic column (sequences I-IV) are silty, white-gray to beige-brown, calcareous marls. They exhibit color and texture variations at different scales, from thin laminae to homogeneous beds up to $40 \mathrm{~cm}$ thick. Under the modern, tilled surface lies a 150 cm-thick sequence ("sequence I") of whitish gray and lightbeige marls (layers L1 to L10). Within this section, at a stratigraphic depth of $90 \mathrm{~cm}$, a beige marl subsequence (L68) becomes distinctively darker near the fault zone (L7a). Underlying sequence I, sequence II (L11 to L21) is a 65$\mathrm{cm}$-thick series of beige and light-brown layers (L11-16) displaying liquefaction patterns, and beige to dark brown units (L17-21) affected by local erosion. Sequence III (L2230 ) is a $100-\mathrm{cm}$-thick package of beige marl beds, each 10$15 \mathrm{~cm}$ thick. Sequence IV (L31-35) is a 55-cm-thick set of very distinctive units, corresponding to the base of the overall marl series. Near its top, layer L34 displays evidence of pervasive bioturbation. The deepest unit in sequence IV comprises thinly laminated gray/green marls (L35), with a relatively high clay content.

The brown-to-red clay units at the bottom of the trench (sequences V-VII) are smoothly stratified, with typical thicknesses ranging from $\sim 1 \mathrm{~mm}$ to more than $20 \mathrm{~cm}$. Sequence $\mathrm{V}(50 \mathrm{~cm}$ thick) is topped by a distinctive, thin bed of light-blue clay (L36), directly overlying mottled yellowbrown beds. The base of the sequence is marked by a very 

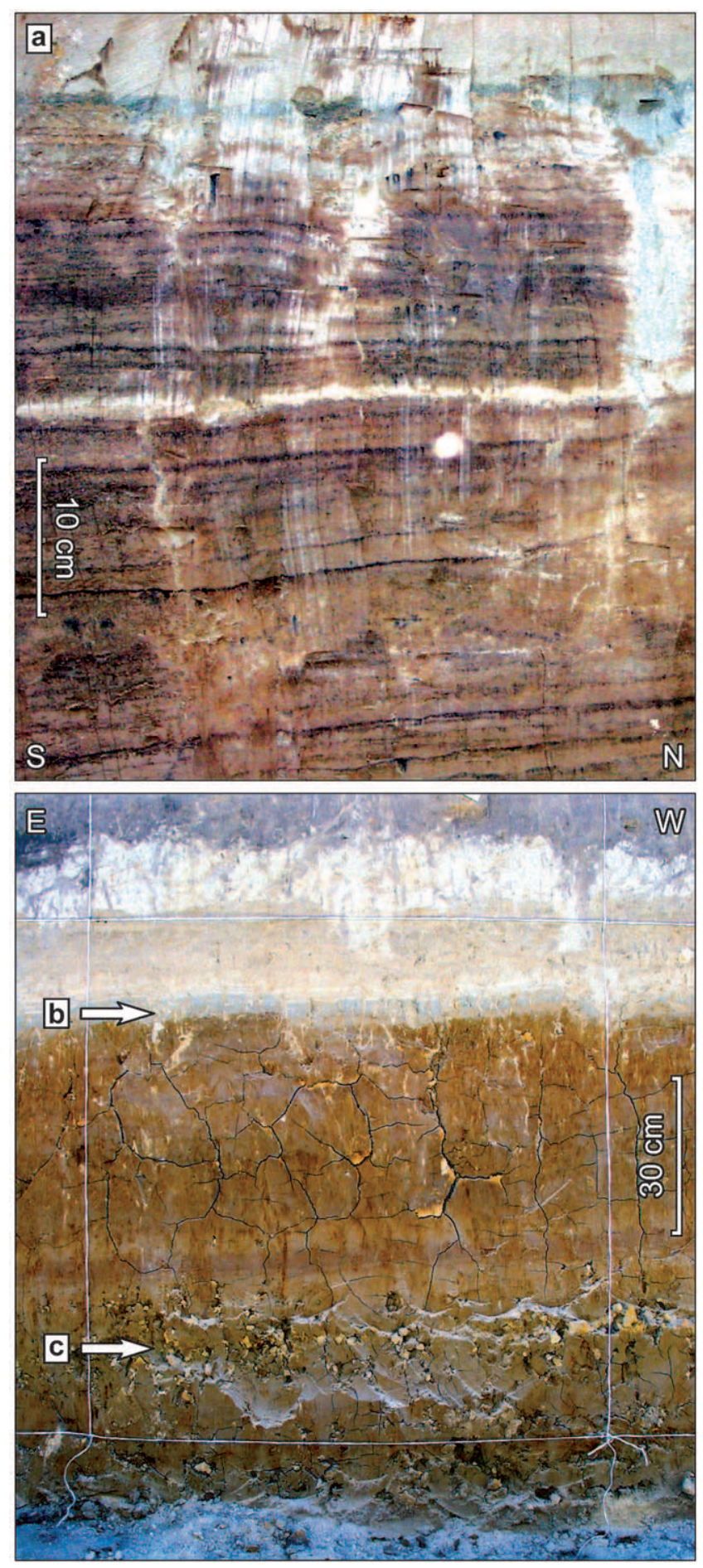

Figure 5. Sediments exposed in the Yammoûneh paleolake. (a) Peat laminae in the Baloua pit (location in Fig. 4b). Marl/clay interface (b) and calcareous nodules (c) exposed in the Kazzâb trench.

distinctive, red-brown double bed (L47). The clay beds of sequence VI (L48-54, $90 \mathrm{~cm}$ thick) are of similar aspect to that of the sequence above it, except for the pervasive presence of 5- to 50-mm-wide calcareous concretions (Fig. 5c), which we interpret as nodules that crystallized around sand grains or gravels. The deepest clay section, sequence VII, comprises relatively uniform clays, with no nodules. Only two darker layers (thin beds L55 and L58), are distinctive enough to be used as stratigraphic markers.

\section{Age Constraints}

Time constraints were derived from accelerator mass spectrometry (AMS) radiocarbon dating of mostly detrital charcoal and a few wood fragments sampled in various layers. Radiocarbon dating of gastropod shells from the upper marl series was also attempted, but the resulting apparent ages came out systematically older than $8 \mathrm{ka}$, even within centimeters of the surface. We interpret this as a reservoir effect resulting from the karstic origin of the paleolake waters.

Due to practical issues and a tight field schedule, samples from wall $\mathrm{K}$ were collected along broad stretches of the wall on both sides of the fault. Many samples were thus collected outside of the area shown in Figure 7. However, taking advantage of the remarkably continuous and colordistinctive stratigraphy, we were able to trace the sampled layers laterally and identify them with specific logged units near the fault zone. We discarded samples for which the lateral correlation appeared to be unreliable. The stratigraphic positions of all "reliable" samples are reported in Figure 6, and the corresponding radiocarbon ages in Table 4.

The tree-ring-calibrated ages of our samples follow a generally monotonic function of stratigraphic depth (Fig. 6). Near the surface (sequence I), the dates are consistent with a sedimentation rate of 0.6 to $0.75 \mathrm{~mm} / \mathrm{yr}$. Within sequence III, the age distribution reflects a slower rate of $\sim 0.4 \mathrm{~mm} /$ yr. We do not use samples from sequences $\mathrm{V}$ and below to estimate the latter value, because there is ample evidence of bioturbation in sequence IV, implying a different depositional setting than in sequence III.

Due to a lack of samples between sequences I and III, the age-depth function for sequence II is unknown. Assuming that the stratigraphic record is continuous and sedimentation rates constant within each sequence would yield an approximate rate of $0.2 \mathrm{~mm} / \mathrm{yr}$ in this sequence. We suspect, however, that a more likely explanation is that part of the stratigraphic record is missing. Although there is little evidence of widespread pedogenesis, as would be expected if sedimentation had stopped altogether for a significant amount of time, layers L(17/18)b to L21 are angularly truncated and capped, west of the fault zone, by layer L16 (Fig. 7). Based on this observation, we favor the hypothesis that part of the sedimentary record has been removed through erosion, possibly by eolian processes or transient channels, due to complete or partial drying-up of the lake. Testing this inference will require direct dating of sequence II and investigating the overall paleoclimatic record in the basin.

Whatever the origin of the age-data gap within sequence II, the ages of units L11 to L21 are for now loosely constrained between $2025 \pm 102$ and $6420 \pm 137$ cal yr B.P. 


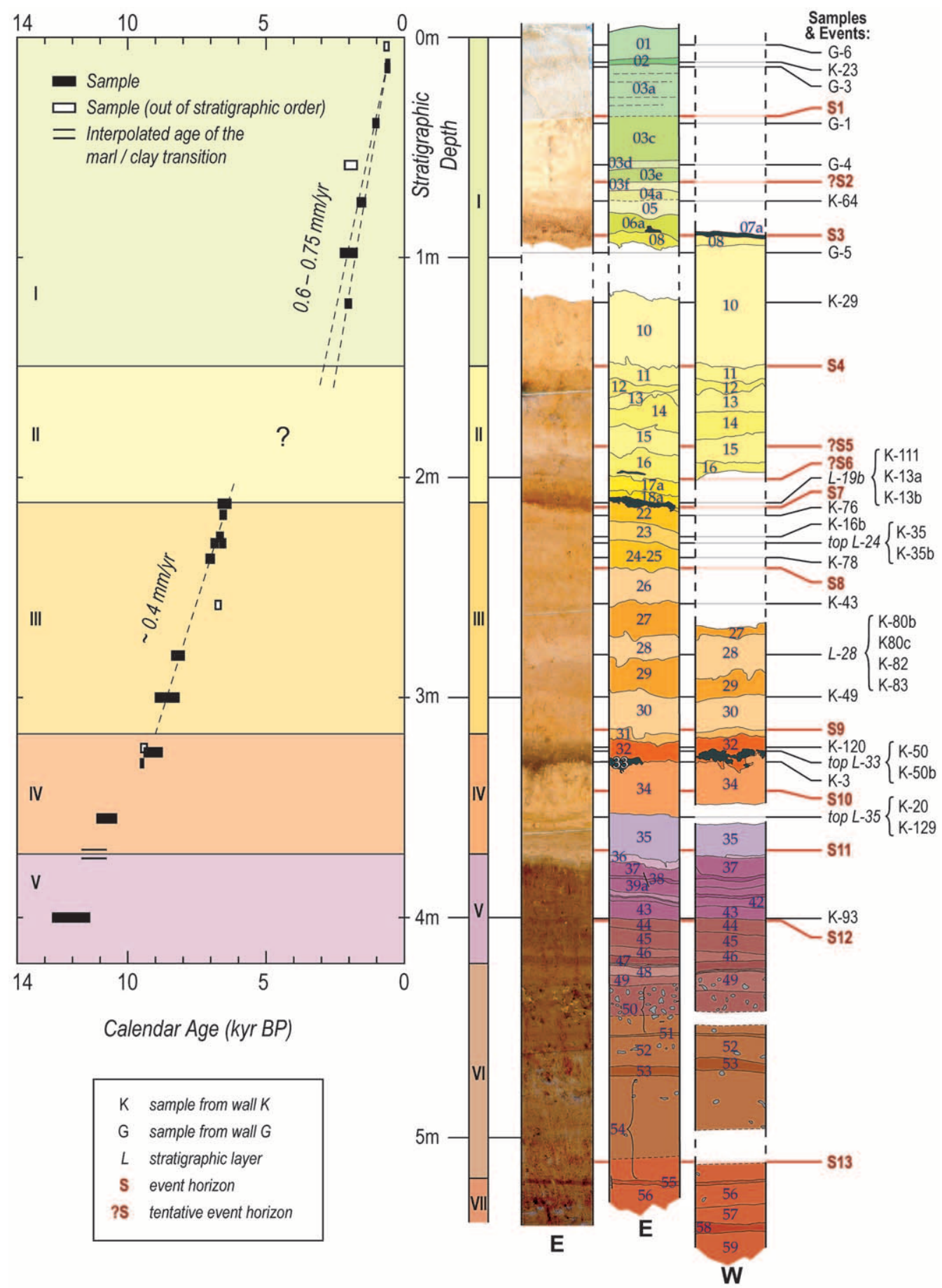

Figure 6. Stratigraphic log of the Kazzâb sediments, east (E) and west (W) of the fault zone, with vertical positions of dated samples and event horizons. The main sedimentary sequences (I-VII) are shown left of the stratigraphic columns, as well as a plot of the calibrated ages of radiocarbon samples versus depth (cf. Table 4).

\section{Paleoseismic Events}

\section{Evidence for Paleoseismic Deformation}

The 2-m-wide zone of faulted, warped, and offset lake beds observed on wall K (Plate 1, Fig. 7) coincides not only with our initial surface mapping, but also with the fault lo- cation previously deduced from resistivity data (Besançon, 1968). This is the only significant deformation zone observed along the entire length $(75 \mathrm{~m})$ of the trench. Subsequent trenches across much of the width of the paleolake exposed no additional fault zone. Although we cannot rule out minor active faulting elsewhere in the basin, particularly 


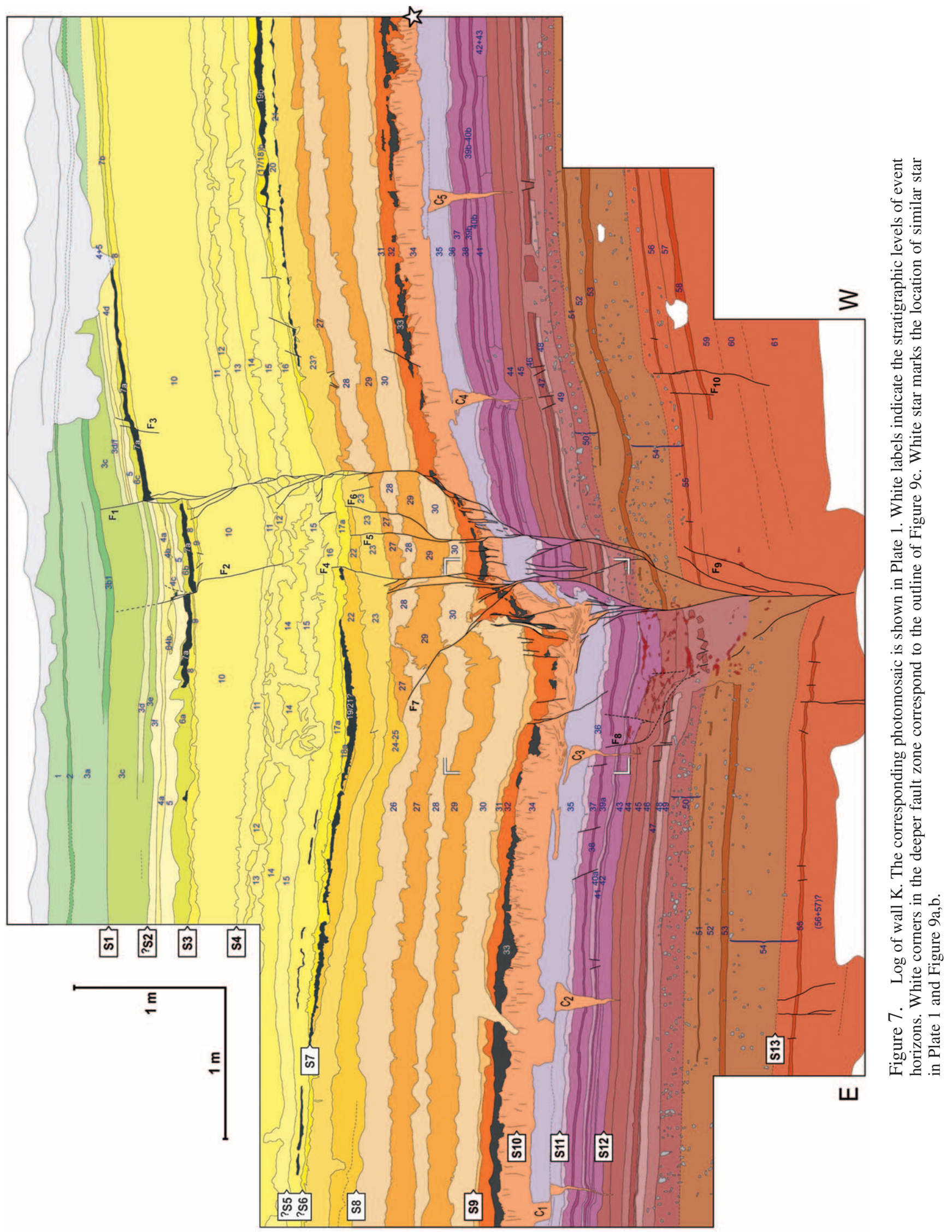



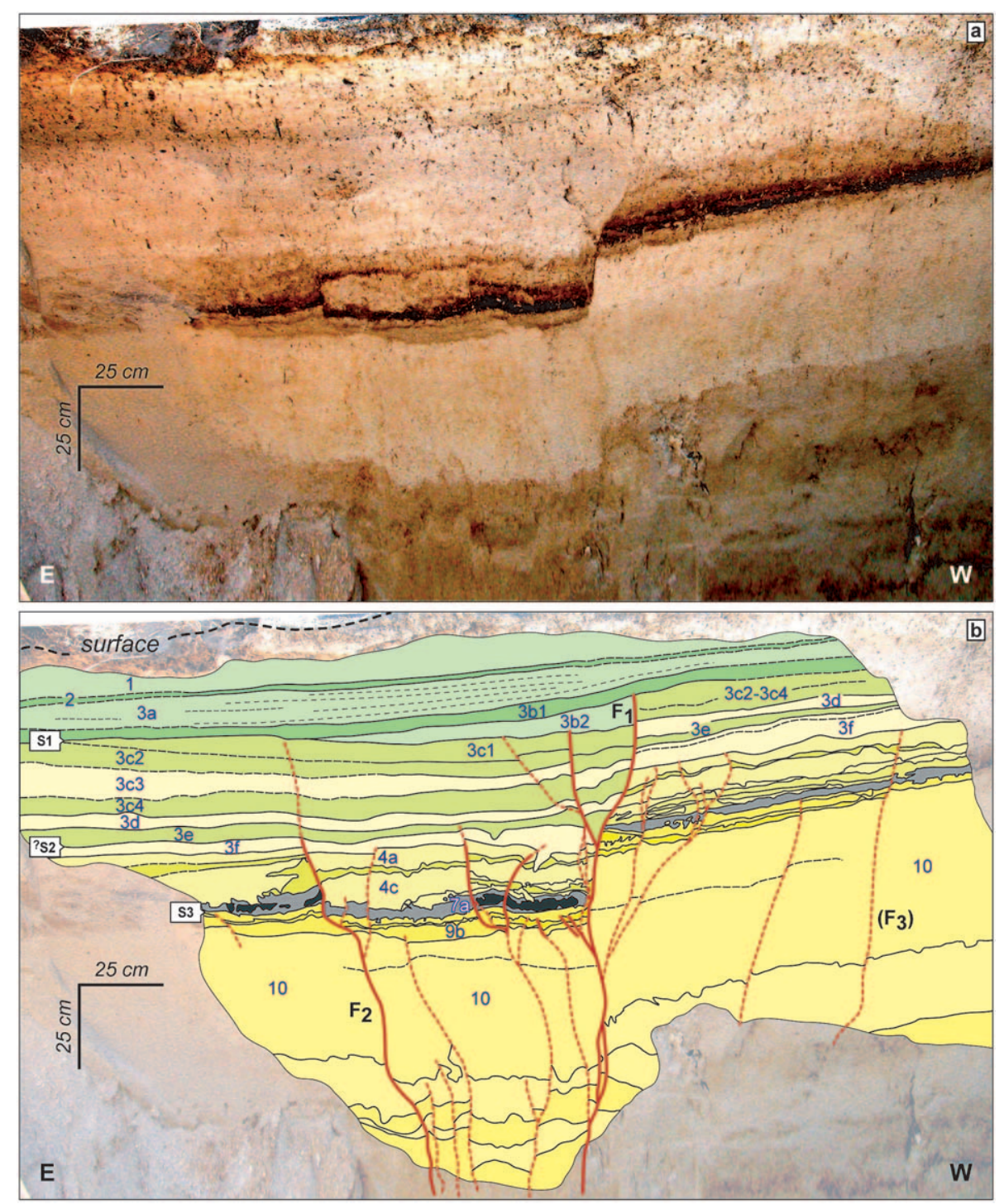

Figure 8. Wall G. (a) Photograph of trench wall G. (b) Corresponding log, with labels marking the stratigraphic levels of event horizons. The shaded area in the lower part of the log corresponds to backfill and rough parts of the wall.

along the eastern paleoshoreline, all the available evidence suggests that the fault zone observed in the Kazzâb trench is the current locus of most, if not all, of the strike-slip motion along the Yammoûneh fault at this location.

On vertical cross-sections of a strike-slip fault, such as shown in Figures 7 and 8, offsets appearing as "vertical" can result from a small component of dip-slip, and/or from the horizontal motion of beds with a fault-parallel dip component. Overall, the lake beds, which are horizontal away from the fault zone, progressively bend down within $\sim 5 \mathrm{~m}$ of the fault. The upper marl sequence is $\sim 90 \mathrm{~cm}$ thicker east of the fault than west of it, corresponding to a cumulative "vertical" down-throw of the clay/marl transition (Plate 1, Fig. 7). Certain darker layers (e.g., L7a and L19/21), are only observed locally, in sags produced by flexure of the beds near the fault. The fault zone is composed of branches that for the most part merge downward at various depths. However, certain layers (e.g., L4-10, L15-23, L34-45) are cut and offset by smaller faults and cracks that cannot be traced down to the central fault zone.

Next is a detailed description of the observed coseismic deformations. Overall, we interpret these observations as evidence for up to 13 paleoearthquakes down to a stratigraphic depth of $\sim 5 \mathrm{~m}$. We discuss these events from youngest to oldest, and label them accordingly from S1 to S13. Evidence for some of these events is somewhat ambiguous, as denoted by the label "?S," and will need to be investigated further.

Event S1. On wall K, layer L3c is cut by a subvertical break $\mathrm{F} 1$ which uplifted $\mathrm{L} 3 \mathrm{~d} / \mathrm{f}$ by 10 or $15 \mathrm{~cm}$, depending on whether L3d/f is the western continuation of L3d or L3f 
Table 3

Detailed Stratigraphic Units

\begin{tabular}{|c|c|c|}
\hline Sequence & Unit & Notes \\
\hline \multirow[t]{14}{*}{ I } & 1 & $\begin{array}{l}\text { Whitish calcareous marl with submodern, millimeter thick roots, and freshwater gastropod shells (1-4 mm) similar to } \\
\text { those observed in the active channels of the modern basin. }\end{array}$ \\
\hline & 2 & Darker gray marl, with small fragments of charcoal. \\
\hline & $3 \mathrm{a}$ & Similar to L1, but with $\sim 2$-cm-thick sublayers and much fewer roots. \\
\hline & $3 \mathrm{~b} 1$ & $\begin{array}{l}\text { Gray marl. Although parallel to L3c west of the fault zone, L3b1 appears to trancate L3b2 and possibly L } 3 c \text { east of } \\
\text { the fault zone. }\end{array}$ \\
\hline & $3 \mathrm{~b} 2,3 \mathrm{c}$ & Light-gray marl. \\
\hline & $3 \mathrm{~d}, \mathrm{e}, \mathrm{f}$ & Alternating layers of whitish and beige marl. \\
\hline & $4 \mathrm{a}$ & Light-brown marl. \\
\hline & $4 \mathrm{~b}$ & Darker brown unit, locally chocolate colored, with detrital charcoal and organic matter. \\
\hline & $4 \mathrm{c}, 5$ & Similar to L4a. \\
\hline & $6 a, b, c$ & Darker beige marl. \\
\hline & $7 \mathrm{a}$ & Dark-brown, clay-rich marl, observed only near the fault zone. \\
\hline & 8 & Lighter brown marl. \\
\hline & 9 & Dark brown marl, observed only near the fault zone. \\
\hline & 10 & Rather homogeneous, 50-cm-thick bed of beige marl, with brownish, subvertical streaks. \\
\hline \multirow[t]{8}{*}{ II } & $11-15$ & $\begin{array}{l}\text { 50-cm-thick succession of beige and light-brown units, locally disturbed by liquefaction, particularly near the fault } \\
\text { zone, resulting in contorted outlines. Some beds (L12, L14) are locally interrupted by injections from contiguous } \\
\text { units. }\end{array}$ \\
\hline & 16 & $\begin{array}{l}\text { Brown bed with a contorted top and a smoother base. East of the fault zone, it caps and truncates L17a. In the West } \\
\text { block, its base truncates angularly L17-21 and the top of L23. Because the top of L16 remains parallel to the } \\
\text { overlying beds, the thickness of this unit increases significantly toward the fault above the eroded section. }\end{array}$ \\
\hline & $17 \mathrm{a}$ [East] & Slightly darker brown bed, unaffected by liquefaction. It rests in a 2-m-wide sag. \\
\hline & $18 \mathrm{a}, 19 / 21$ [East] & Darker clay-rich marl, coating the bottom of the sag. \\
\hline & $(17 / 18) b[$ West] & Light-brown marl, angularly truncated by the base L16. \\
\hline & 19 [West] & Thin, distinctive bed of brown marl, angularly truncated by the base L16. \\
\hline & 20 [West] & Beige marl, angularly truncated by the base L16. \\
\hline & 21 [West] & Thin, distinctive bed of brown marl, angularly truncated by the base L16. \\
\hline III & $23-30$ & $\begin{array}{l}\text { Package of alternating lighter and darker beige marl beds, each } 10-\text { to } 15 \text {-cm thick. This sequence is } \sim 40 \mathrm{~cm} \text { thicker } \\
\text { east than west of the fault zone. Facies comparisons across the fault suggest that the units missing in the western } \\
\text { block are L24-26 and the upper part of L27, although this interpretation is not unique. }\end{array}$ \\
\hline \multirow[t]{4}{*}{ IV } & 31 & 3-cm-thick whitish marl bed, topped by a characteristic, ocher horizon. \\
\hline & $32-33$ & $\begin{array}{l}\text { Gray marl beds with irregular thickness ( } 10 \mathrm{~cm} \text { on average), darkest at the base. The sediments of L33 exhibit darker } \\
\text { patches rich in organic matter, and the base of this unit forms an irregularly contorted surface. }\end{array}$ \\
\hline & 34 & $\begin{array}{l}\text { 25-cm-thick bed of whitish/light-gray marl. This unit displays evidence of pervasive bioturbation, probably by roots } \\
\text { or by burrowing organisms, in the form of subvertical gray streaks of variable lengths that extends downward } \\
\text { from the base of L33. It also displays evidence of plastic flow/liquefaction, outlined by the folding of the } \\
\text { bioturbation marks, chiefly localized within a few meters of the fault zone. }\end{array}$ \\
\hline & 35 & $\begin{array}{l}\text { 20-cm-thick bed of gray- to light-green marls with a relatively high clay content, with thin laminae of alternating } \\
\text { green and whitish colors. The base of L35 is generally lighter than its top. }\end{array}$ \\
\hline \multirow[t]{6}{*}{ V } & 36 & ３-cm-thick bed of light-blue clay. \\
\hline & 37 & Mottled yellow-brown, poorly defined clay beds. \\
\hline & $37-46$ & Relatively uniform succession of clay beds. \\
\hline & 38 & Distinctive, 10-mm-thick dark lamina. \\
\hline & 41 & Distinctive, 5-mm-thick dark lamina. \\
\hline & 47 & $\begin{array}{l}\text { Very distinctive, dark red-brown double layer, comprising a } 30 \text { - to } 35 \text {-mm-thick bed overlying a } 5 \text {-mm-thick laminae } \\
\text { of similar color and texture. L47 is very uniform across the whole trench. }\end{array}$ \\
\hline VI & $48-54$ & $\begin{array}{l}\text { Less than } 10 \mathrm{~cm} \text { below the base of L47 begins a level with abundant calcareous nodules. It is difficult to map } \\
\text { individual beds within this nodular unit, in part, because the concretions prevent proper smoothing of the trench } \\
\text { wall. One can nevertheless map two darker layers, L51 }(1 \mathrm{~cm} \text { thick) and L53 }(5 \mathrm{~cm}) \text {, which are clear enough to } \\
\text { act as deformation markers }\end{array}$ \\
\hline VII & $55-59$ & $\begin{array}{l}\text { Immediately beneath the nodular level, the dark-brown bed L55 is the deepest distinctive clay bed recognizable on } \\
\text { both sides of the fault zone. A lower layer L58 can be mapped in the western block, } \sim 20 \mathrm{~cm} \text { below L55, but it } \\
\text { lies deeper than the base of wall } \mathrm{G} \text { east of the fault. }\end{array}$ \\
\hline
\end{tabular}

Corresponding strategraphic log is shown in Figure 6. 
Table 4

Radiocarbon Dates

\begin{tabular}{|c|c|c|c|c|c|c|c|c|}
\hline Sample & Layer & $\begin{array}{l}\text { Depth } \\
(\mathrm{cm})\end{array}$ & Lab Ref. & $\begin{array}{l}\delta^{13} \mathrm{C} \\
(\% \circ)\end{array}$ & $\begin{array}{c}\text { Fraction Modern } \\
\qquad(\% \circ)\end{array}$ & $\begin{array}{l}\delta^{14} \mathrm{C} \\
(\%)\end{array}$ & $\begin{array}{l}{ }^{14} \mathrm{C} \text { Age } \\
\text { (yr B.P.) }\end{array}$ & 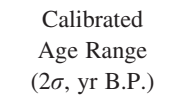 \\
\hline G6* & 1 & 4 & 12237 & -29.3 & & & $718 \pm 35$ & $566-727$ \\
\hline K23 & 2 & 12 & 85982 & -25 & $927.1 \pm 5.1$ & $-72.9 \pm 5.1$ & $610 \pm 45$ & $540-662$ \\
\hline G3 & (top) $03 \mathrm{a}$ & 14 & 12234 & -28.5 & & & $650 \pm 60$ & $539-684$ \\
\hline G1 & $03 b$ & 39 & 12233 & -25.3 & & & $1,115 \pm 35$ & $935-1,125$ \\
\hline G4* & $03 \mathrm{f}$ & 58 & 12235 & -21 & & & $1,980 \pm 90$ & $1,711-2,153$ \\
\hline K64 & $04 b$ & 74 & 86069 & -25 & $815.5 \pm 4.3$ & $-184.5 \pm 4.3$ & $1,640 \pm 45$ & $1,411-1,691$ \\
\hline G5 & (top) 10 & 98 & 12236 & -32.6 & & & $2,000 \pm 100$ & $1,714-2,301$ \\
\hline K29 & 10 & 121 & 85984 & -25 & $774.1 \pm 3.5$ & $-225.9 \pm 3.5$ & $2,055 \pm 40$ & $1,924-2,127$ \\
\hline K111 & $19 \mathrm{~b}$ & 212 & 86077 & -25 & $497.3 \pm 3.7$ & $-502.7 \pm 3.7$ & $5,610 \pm 70$ & $6,283-6,556$ \\
\hline K13a & $19 \mathrm{~b}$ & 212 & 85977 & -25 & $495.6 \pm 2.8$ & $-504.4 \pm 2.8$ & $5,640 \pm 50$ & $6,305-6,533$ \\
\hline $\mathrm{K} 13 \mathrm{~b}$ & $19 \mathrm{~b}$ & 212 & 85978 & -25 & $486.3 \pm 2.5$ & $-513.7 \pm 2.5$ & $5,790 \pm 45$ & $6,478-6,719$ \\
\hline K76 & 22 & 217 & 86070 & -25 & $488.8 \pm 2.3$ & $-511.2 \pm 2.3$ & $5,750 \pm 40$ & $6,449-6,652$ \\
\hline K16b & (bottom) 23 & 227 & 85979 & -25 & $482.5 \pm 2.2$ & $-517.5 \pm 2.2$ & $5,855 \pm 40$ & $6,557-6,778$ \\
\hline K35 & (top) 24 & 230 & 85987 & -25 & $487.6 \pm 2.3$ & $-512.4 \pm 2.3$ & $5,770 \pm 40$ & $6,473-6,667$ \\
\hline K35b & (top) 24 & 230 & 85988 & -25 & $472.4 \pm 2.1$ & $-527.6 \pm 2.1$ & $6,025 \pm 40$ & $6,750-6,976$ \\
\hline K78 & 24 & 237 & 86071 & -25 & $467.5 \pm 2.1$ & $-532.5 \pm 2.1$ & $6,105 \pm 40$ & $6,885-7,158$ \\
\hline $\mathrm{K} 43^{*}$ & (top) 27 & 258 & 85993 & -25 & $480.1 \pm 2.1$ & $-519.9 \pm 2.1$ & $5,895 \pm 40$ & $6,637-6,831$ \\
\hline K83 & 28 & 281 & 86075 & -25 & $406.8 \pm 2$ & $-593.2 \pm 2$ & $7,225 \pm 40$ & $7,966-8,161$ \\
\hline K80c & 28 & 281 & 86093 & -25 & $406.7 \pm 2.1$ & $-593.3 \pm 2.1$ & $7,230 \pm 45$ & $7,968-8,163$ \\
\hline K80b & 28 & 281 & 86072 & -25 & $401.2 \pm 2$ & $-598.8 \pm 2$ & $7,335 \pm 45$ & $8,018-8,302$ \\
\hline K82 & 28 & 281 & 86074 & -25 & $397 \pm 4.5$ & $-603 \pm 4.5$ & $7,420 \pm 100$ & $8,025-8,400$ \\
\hline K49 & (top) 30 & 300 & 85994 & -25 & $386 \pm 8.6$ & $-614 \pm 8.6$ & $7,650 \pm 180$ & $8,158-8,993$ \\
\hline $\mathrm{K} 120 *$ & 32 & 323 & 86078 & -25 & $351.3 \pm 1.4$ & $-648.7 \pm 1.4$ & $8,405 \pm 35$ & $9,308-9,519$ \\
\hline $\mathrm{K} 50 \mathrm{~b}$ & (top) 33 & 325 & 86066 & -25 & $367.2 \pm 1.9$ & $-632.8 \pm 1.9$ & $8,045 \pm 45$ & $8,768-9,032$ \\
\hline K50 & (top) 33 & 325 & 85995 & -25 & $358 \pm 1.6$ & $-642 \pm 1.6$ & $8,250 \pm 40$ & $9,090-9,403$ \\
\hline K3 & (bottom) 33 & 330 & 85976 & -25 & $348.6 \pm 1.6$ & $-651.4 \pm 1.6$ & $8,465 \pm 40$ & $9,436-9,533$ \\
\hline K20 & (top) 35 & 355 & 85981 & -25 & $312.8 \pm 1.6$ & $-687.2 \pm 1.6$ & $9,335 \pm 45$ & $10,414-10,683$ \\
\hline K129 & (top) 35 & 355 & 86080 & -25 & $306.3 \pm 2.5$ & $-693.7 \pm 2.5$ & $9,510 \pm 70$ & $10,587-11,100$ \\
\hline K93 & (top) 44 & 400 & 86076 & -25 & $277.9 \pm 6.2$ & $-722.1 \pm 6.2$ & $10,290 \pm 190$ & $11,389-12,705$ \\
\hline
\end{tabular}

Samples K29 and K82 are partly carbonized wood fragments. K13b, K76, and K49 are crushed charcoal, locally mixed with marly sediments. All other samples are detrital charcoal fragments. "K" samples were processed at Lawrence Livermore National Laboratory's Center for AMS, and "G" samples at the Van de Graaff laboratory of the University of Utrecht. For all " $\mathrm{K}$ " samples, $\delta^{13} \mathrm{C}$ was assumed to be $-25 \%$. C-14 ages were converted to calendar years using OxCal 4 33 (Bronk Ramsey, 1995, 2001) with terrestrial calibration curve IntCal04 (Reimer et al., 2005). Only four samples, marked *, appear to be out of stratigraphic order.

(Fig. 7). The corresponding change in L3c thickness, from $25 \mathrm{~cm}$ east of the fault, to $15 \mathrm{~cm}$ west of it, implies erosion of the upper section of western L3c. This is consistent with the observation on wall G (Fig. 8) of a wedge of lighter marl (L3b2) that we interpret as a colluvial deposit resulting from erosion of a coseismic scarplet where F1 pierced the surface. After emplacement of L3b2, the darker layer L3b1 sealed F1. This event, S1, must predate L3b1 but postdate L3c, and the colluvial wedge L3b2 is expected to contain material reworked from $\mathrm{L} 3 \mathrm{c}$.

Event ?S2. Two other breaks, F2 and F3 (Figs. 7 and 8), cut and offset the dark layer L7a by $5 \mathrm{~cm}$ about $50 \mathrm{~cm}$ to the east and west of F1. F3 can be traced upward to the base of L3d/f, but mapping its upward continuation is impossible because of poor exposure of the sediments near the modern surface. F2 can be precisely mapped up to L3f. While this could be interpreted as evidence of an event ?S2 roughly coeval with L3e-f, layers L3e to L3c are systematically warped above F2, consistent with the observed offset of L7a.
This is observed on both walls $\mathrm{K}$ and $\mathrm{G}$. On the latter, the base of L3b1 is similarly warped, making this layer thicker to the west of F2. Since the base of L3b1 marks the S1 event horizon, we favor the interpretation that F2 and F3 formed during S1, propagating above L3f in a slightly less localized fashion, and forming a 70-cm-wide, 10- to 20-cm-deep graben at the surface. Such surface deformation is typical of en-echelon features ("mole tracks") commonly observed along strike-slip ruptures (e.g., Emre et al., 2003; Klinger et $a l .$, 2005). If distinct from $\mathrm{S} 1$, however, ?S2 could be argued to postdate $\mathrm{L} 4 \mathrm{a}$ and predate $\mathrm{L} 3 \mathrm{e}$.

Event S3. In the middle of the down-thrown block between $\mathrm{F} 1$ and F2, the base of L7a is sharp, linear, and undisturbed. By contrast, just beneath this continuous marker, L9 is disrupted by several oblique breaks with apparent thrust components (Figs. 7, 8). The two westernmost breaks merge with the downward continuation of the main fault (F1). The corresponding event (S3) must postdate L9 and predate L7a. 

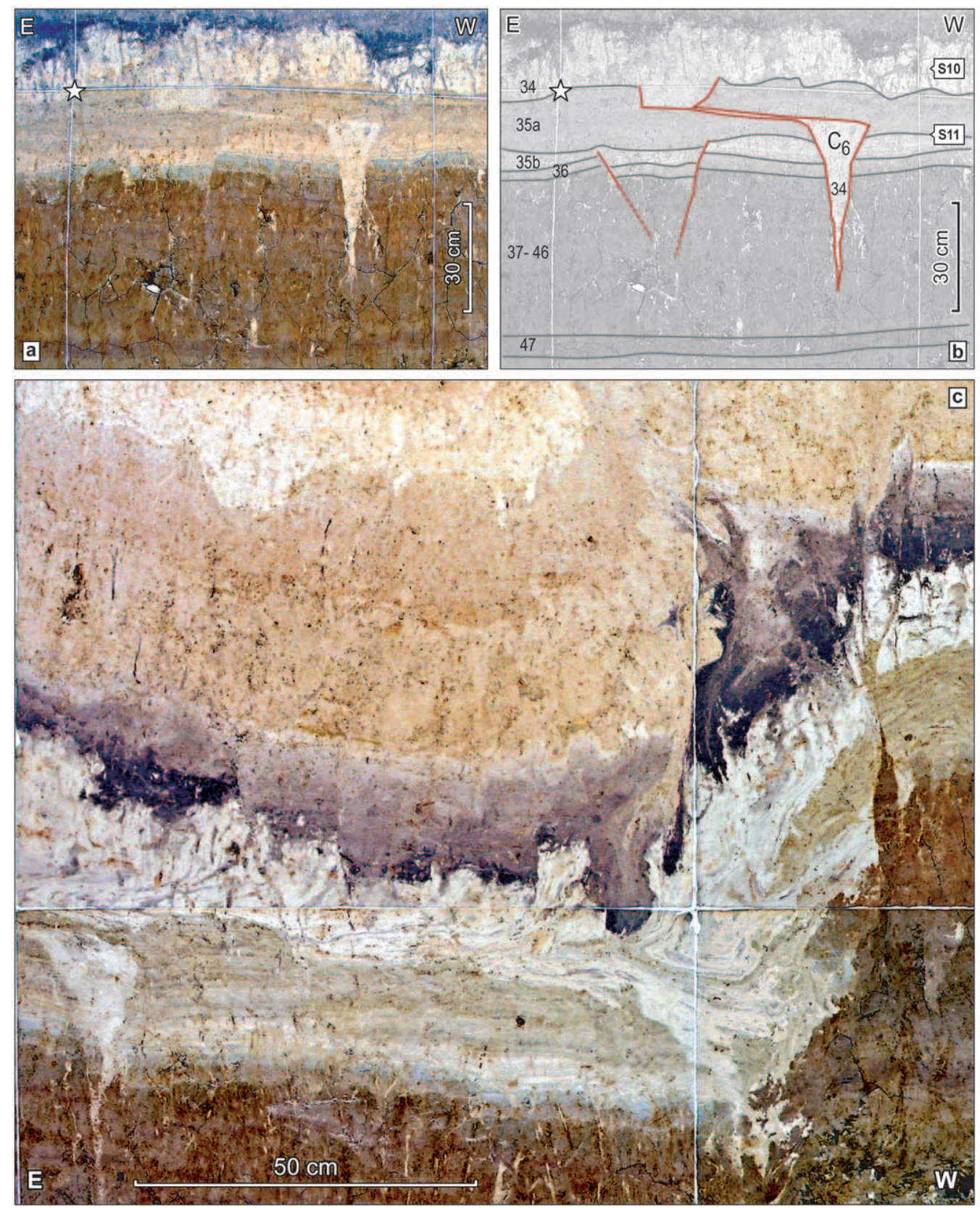

Figure 9. Examples of coseismic deformation. (a, b) One of several bayonet-shaped cracks that systematically open in L35, taper down to L44-45, and are filled with L34 (see discussion in text). Note the shallow décollement in L35a. The dark bioturbation marks in L34 appear to be unaffected by the crack. The white star shows the location of the similar stars in Plate 1 and Figure 7. (c) Pre-existing bioturbation marks record east-directed flow of whitish marl (L34) in the fault zone. The outline of this photograph is shown as white corners in Figure 7.

Event S4. Directly adjacent to F1, the base of L10 is warped upward over a width of $\sim 20 \mathrm{~cm}$, above two breaks which splay off from F1 and cut layers L12 to L16. East of the fault zone, L10 tapers eastward over a few meters. By contrast, the western section of L10 displays no thickness change, in keeping with the general geometry of the lake beds.
We interpret this tapering as a result of faultward tilting and deformation of the top of L11 due to event S4, and of subsequent deposition of L10 over the west-dipping top of L11, restoring a horizontal surface. Although small-scale warping of L11-12 can be interpreted as direct coseismic deformation, the larger-scale tilting of L11 may be related to liquefaction within underlying layers. Indeed, directly be- 
low the tapering section of L10, layers L12 to L15 exhibit irregular, convoluted features, reminiscent of fluid mixing, probably due to thixotropy within the superficial, watersaturated lake beds during S4. In support of this interpretation, a sand-blow/mud fountain was observed at the base of L10, about $40 \mathrm{~m}$ west of the fault zone. The S4 horizon would thus correspond to the top of L11. Note that the contorted shapes of the thixotropic sediments make it difficult to trace the downward continuation of F2, even though it postdates liquefaction.

Event ?S5. From minor breaks that cut L16 just east of F1 and terminate upward into fissures filled with L15 deposits, and from small, coeval faults that offset L21-16 west of F1 and reach the base of L15, we infer the existence of event ?S5. This tentative event would therefore postdate L16 and predate the end of deposition of L15. An alternative interpretation would be that these breaks formed during S4, with liquefied marl from L15 flowing into the cracks during the shaking.

Event ?S6. L17a is offset vertically by $5 \mathrm{~cm}$ across the subvertical fault F4. Although the break is sharp and clear in L17a, it does not appear to offset the top of L16, in contrast with the filled-in cracks observed at the top of L16 (see previously, ?S5). There is no discernible evidence that F4 connects upward with F2 across layers L15-12. This lack of evidence cannot result directly from liquefaction, since F2 clearly postdates S4. At most, the convoluted shapes of L1512, predating F2, could make it less easy to observe a connection. Thus, based on the sharpness of F4 in L17a and its disappearance within the well-preserved layer L16, we conclude that it might result from a tentative event (?S6) postdating L17a and possibly coeval with L16.

Event S7. Between F1 and F4, the base of L22 is offset by a subvertical break F5. About $20 \mathrm{~cm}$ to the west, L22 disappears altogether, as L23 is brought up in contact with L17a by another fault, F6. Whether F6 offsets the base of $\mathrm{L} 17 \mathrm{a}$ is debatable, but there is no doubt that L17a seals the top of F5. Thus an event (S7), distinct from ?S6, must have occurred between deposition of L22 and that of L17a.

About $1 \mathrm{~m}$ east of F4, units L18a and L19/21 accumulated locally in a shallow trough. These dark, clay-rich beds were likely deposited locally in sags resulting from coseismic ground rupture. L7a, which is observed only within $\sim 1 \mathrm{~m}$ of the fault, capping the $\mathrm{S} 3$ horizon, likely has a similar origin. Thus, in the absence of a direct dating of L17a, we propose that S7 is roughly coeval with L19b.

Event S8. East of F1, layers L26-28 have been eroded by L23 and L24-25 due to strong folding of L26-29. This deformation results from $30-40 \mathrm{~cm}$ of thrust motion on a $45^{\circ}$ west-dipping fault, F7. We interpret such thrusting as an example of local shortening caused by surface rupture irregularities, in this case, an en-echelon pressure ridge. On top of this ridge, L26 has been completely removed and only part of L27 remains. It is likely that the subvertical faults just east of F4, which terminate abruptly where they reach the base of L23, formed during the same event (S8), which postdates L26. L24-25, which exists only east of F7, is likely derived from material eroded from the folded and uplifted layers L26-27. Thus the oldest layer that unambiguously postdates the event is L23.

Event S9. Numerous breaks affect layers L31-34, terminating within or at the top of L31 (see close-up in Fig. 9c). This event (S9) clearly postdates L31 and predates deposition of the top of L30. Faulting associated with S9 is broadly distributed, mostly within a couple of meters east of F1. This distributed rupture pattern might be related to mechanical coupling between the thin L34-35 marl cover and the clay sequence underneath.

Additionally, within $\sim 1 \mathrm{~m}$ of the fault zone, the white marl of L34 displays widespread evidence of plastic flow, beautifully highlighted by the facies of L34 (Fig. 9c). Such flow is particularly spectacular in the fault zone, where a large, east-facing, recumbent fold deforms the pre-existing, subvertical bioturbation marks. This pattern can be observed up to $\sim 1 \mathrm{~m}$ farther east, in the form of asymmetric folding of the lower part of L34. We propose that thixotropy and/or water saturation allowed the marls of L34 to flow east, probably due to uplifting of the western block.

The relationship between the flow and bioturbation marks implies that L33 was already in place and L34 bioturbated at the time of liquefaction. Although we cannot rule out that $\mathrm{S} 9$ triggered the flow, there is little evidence for coseismic uplift of the block west of the fault, which should have produced observable vertical separation. Moreover, since S9 disrupted the dark soil layer L32-33 in many places, one might expect that sand-blows of white marl (L34) would have erupted at the surface, above L31, which is not observed.

An alternative interpretation is that liquefaction was caused by S8. The vertical motion associated with this event can be traced along F7 down to L33, and its downward continuation corresponds to the locus of strongest flow. The $\sim 30 \mathrm{~cm}$ of uplift associated with S8 (reflected by the abrupt thickening of layers L22-30) would be consistent with gravity-driven eastward flow of L34.

Event S10. On both sides of the fault zone, the clay/marl interface is cut by several distinctive cracks ( $\mathrm{C} 1$ to $\mathrm{C} 5$ in Fig. 7, C6 in Fig. 9). These fissures are 40 to $50 \mathrm{~cm}$ deep, up to $\sim 15 \mathrm{~cm}$ wide, and rather regularly spaced $(\sim 1.5 \mathrm{~m})$ near the fault zone. Away from the fault, they become smaller and wider spaced. They are all topped by L34 and taper rapidly through the uppermost clay beds, down to L4445. White marl from L34 systematically fills these fissures, with no discernible stratification. Most of the cracks exhibit a peculiar "bayonet" shape (Fig. 9a, b), with an upper part systematically offset to the east relative to the bottom tip. 
The concentration of cracks within $\sim 10 \mathrm{~m}$ on both sides of the fault zone, the absence of colluvial subunits within the fissures, and the rather uniform facies of the marly infill imply that the cracks formed as a result of sudden coseismic deformation rather than desiccation, and that the corresponding event (S10) postdates the deposition of L34. Mechanically, they could result from flexure and broad downwarping of the plastic clay beds. They might also correspond to broadly distributed surface shear related to upward propagation of a seismic rupture. For instance, after the $M_{\mathrm{W}} \sim 7.8$ Kokoxili earthquake of 2001 in Northern Tibet, Klinger et al. (2005) interpreted distributed surface cracking as damage features shortly preceding the main, strike-slip surface break.

It is less straightforward to explain the bayonet geometry. Locally, the lateral offset of each crack results from bedding-parallel slip within the upper, finely laminated L35, but the exact level of décollement varies from one fissure to another. Although the upper parts of the cracks located west of the fault might have slid downslope, thus eastward, this explanation does not hold for cracks located east of the fault. Alternatively, to explain the asymmetry, one might invoke very shallow block rotations about vertical axes, consistent with left-lateral slip, but we found no independent evidence in support of this explanation.

As mentioned earlier, the rather uniform filling of the cracks implies that L34 was present at the time of S10 and flowed rapidly in the fissures. By contrast, within the cracks farthest from the fault zone (e.g., C6, in Fig. 9a, b), the dark, subvertical bioturbation marks in the upper part of L34, as well as the level at the base of L32-33, display no perturbation whatsoever above the fissure. The development of soil and vegetation in L32-33 thus postdates S10.

Event S11. In several places (just east of C3, between F4 and F5, and in the area shown in Fig. 9a), the uppermost clay layers are offset by several fault breaks. Each of the breaks offsets the thin blue clay unit L36, and some of them affect the lowermost part of overlying L35. At most, the vertical offset of L36 is $8 \mathrm{~cm}$ (between F4 and F5). The breaks can be traced downward for a few tens of centimeters, at most down to L46. We interpret these faults to flatten out above L47, some of them accommodating dip-slip motion only, because of downward flexing of the clay beds near the fault zone. The corresponding event, S11, should be roughly coeval with the lower part of L35.

Event S12. The dark red-brown double-layer L47 is downthrown and completely disrupted in the eastern half of the deep part of the fault zone. Only discontinuous fragments of this layer are recognizable near the bottom of a 90-cm-wide, 25-cm-deep half-graben. Recognition of L47 in this halfgraben is unambiguous because of its distinctive appearance. Clay lenses with a peculiar, brick-red color, observed nowhere else in the trench, are interstratified in the half-graben fill, mostly between L41 and L47. This is suggestive of local collapse, accounting for the poor state of preservation of layers L42-47 within the half-graben. The western half of the graben might be missing due to posterior strike-slip (i.e., wall-perpendicular) motion on the fault. Layers younger than L47 are difficult to recognize within the half-graben, although clear thickening is evident below the unaffected layer L41, which smoothly overlies the trough. The corresponding event, S12, thus predates L41 and postdates L47. Unfortunately, the degraded stratigraphic sequence within the graben precludes a more precise assessment.

Event S13. L55 is vertically offset, by up to $5 \mathrm{~cm}$, across numerous small breaks on both sides of the main fault zone. Some, such as F9 or F10, can be traced down to L58-60. These breaks all terminate upward about $5-10 \mathrm{~cm}$ above L55. At this level, between L55 and L53, the thickness of L54 changes abruptly across the main fault zone from 30$36 \mathrm{~cm}(W)$ to $42-46 \mathrm{~cm}(E)$. This is the deepest observed evidence of coseismic deformation in this trench. The corresponding event, S13, predates L53 and postdates the top of L54.

\section{Timing of Events}

Table 5 summarizes the stratigraphic constraints relevant to each event described previously. S1, ?S2, and S3 are well constrained by six radiocarbon dates from sequence I (Fig. 10). K23 and G3 were sampled in units unambiguously postdating $\mathrm{S} 1$. We interpret $\mathrm{L} 3 \mathrm{~b} 2$ as a postseismic colluvial wedge derived from L3c material, implying that G1 predates S1. Event ?S2, in turn, predates G1 and postdates K64. Sample G4 is clearly out of sequence, being older than K64 and similar in age to G5, which are located 16 and $40 \mathrm{~cm}$ below it, respectively (cf. Table 4 and Fig. 6). Event S3 predates K64 and postdates both samples G5 and K29. Figure 10 displays the output of an OxCal Bayesian model for this sequence:

$$
\mathrm{K} 29>\mathrm{G} 5>\mathbf{S 3}>\mathrm{K} 64>\text { ?S2 }>\text { G1 }>\text { S1 }>\text { G3 }>\text { K23, }
$$

where the $>$ sign denotes "is older than." The age bounds predicted by the model are listed in Table 5 .

The events recorded between layers L10 and L19b can only be very loosely constrained to have occurred between 2.0 and $6.4 \mathrm{cal}$ kyr B.P., due to the scarcity of radiocarbon data. Until the sedimentary history of sequence II is elucidated, one cannot assume that our record of events is complete in this section of the trench. Moreover, the ambiguous evidence for ?S5 and ?S6 further detracts from an estimate of the total number of events between 6.4 and $2.0 \mathrm{ka}$. Because the sedimentary sequence between L10 and L11 appears to be continuous, one could argue that a reasonable age estimate for $\mathrm{S} 4$ can be obtained from extrapolating the sedimentation rate in sequence I to the base of L10 (cf. Fig. 6). Doing so would place S4 some time around 2.5$3.0 \mathrm{ka}$. 
Table 5

Stratigraphic and Chronological Constraints on Event Ages.

\begin{tabular}{rlcr} 
& & \multicolumn{2}{c}{ Age Bounds (95.4\%) } \\
\cline { 3 - 4 } Event & Stratigraphic Constraints & A.D./B.C. & B.P. \\
\hline S1 & post L3c, pre L3b1 & A.D. 926-1381 & $569-1,024$ \\
?S2 & post L4a, pre L3e & A.D. 405-945 & $1,005-1,545$ \\
S3 & post L9, pre L7a & 30 B.C. - A.D. 469 & $1,481-1,979$ \\
S4 & post L11, pre L10 & - & $2,115-6,288^{*}$ \\
?S5 & post L16, pre L14 & - & $2,115-6,288^{*}$ \\
?S6 & post L17a, pre L15 & - & $2,115-6,288^{*}$ \\
S7 & coeval L19b & - & $6,324-6,565^{*}$ \\
S8 & post L28, pre L23 & - & $6,645-7,990$ \\
S9 & post L31, pre L30 & - & $8,384-9,001$ \\
S10 & post L35, pre L32 & - & $9,231-10,546$ \\
S11 & post L37, pre top L35 & - & $10,726-12,268$ \\
S12 & post L47, pre L41 & - & $11,389-12,705^{*}$ \\
S13 & post L55, pre top L54 & & $12,047 \pm 658$ \\
\hline
\end{tabular}

Stratigraphic models used to estimate the $95 \%$ age bounds are discussed in the text and displayed in Figures 10 and 11.

*See text.

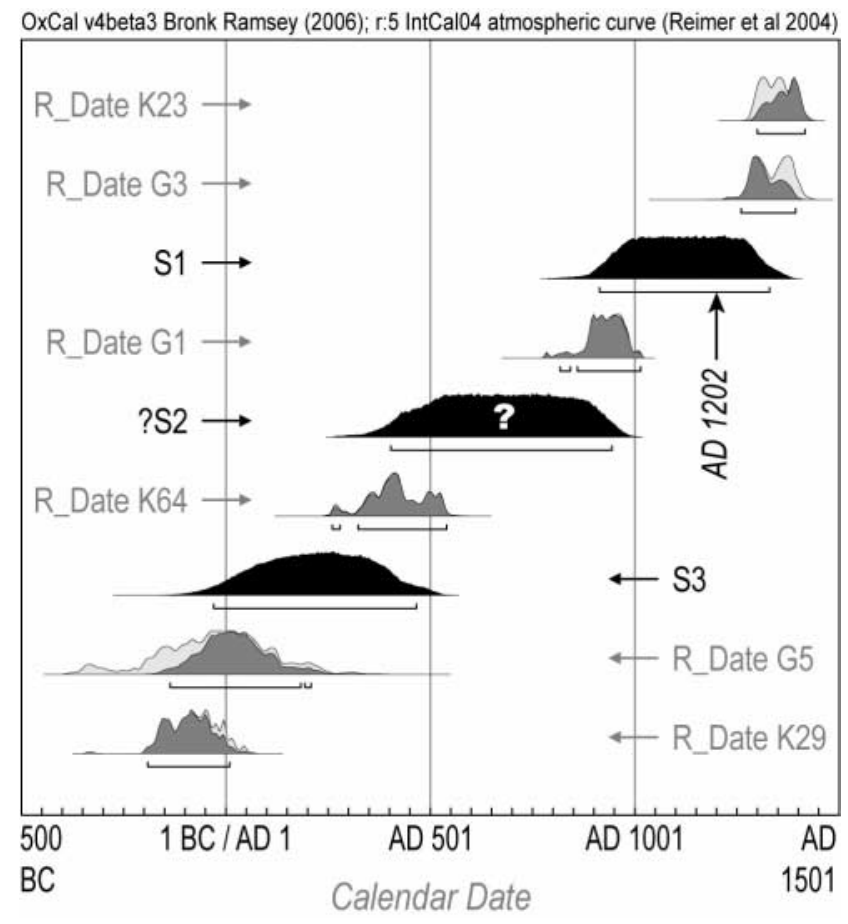

Figure 10. "Historical" series of events. Time probability distributions (TPDs) in light gray are calibrated using terrestrial curve IntCal04 (Reimer et al., 2005). Dark-gray TPDs are modeled using OxCal 4 33 (Bronk Ramsey, 1995, 2001), according to the Bayesian model discussed in the text, and the resulting TPD of events S1-3 are plotted in black. Horizontal bars correspond to $95.4 \%$ confidence limits.

The timing of the events recorded in sequences III-V, by contrast, is constrained by numerous dated samples. Excluding samples K43 and K120, which are out of stratigraphic order (cf. Fig. 6), the stratigraphic relationships be- tween event horizons and radiocarbon samples can be summarized as:

$$
\begin{gathered}
\text { S12 } \approx \mathrm{K} 93>\mathrm{S} 11>\left(\begin{array}{c}
\mathrm{K} 20 \\
\mathrm{~K} 129
\end{array}\right)>\left(\begin{array}{c}
\mathbf{S} 10 \\
\mathrm{~K} 3
\end{array}\right)>\left(\begin{array}{c}
\mathrm{K} 50 \\
\mathrm{~K} 50 \mathrm{~b}
\end{array}\right)>\mathrm{S} 9>\mathrm{K} 49 \ldots \\
\ldots \mathrm{K} 49>\left(\begin{array}{c}
\mathrm{K} 83 \\
\mathrm{~K} 80 \mathrm{c} \\
\mathrm{K} 80 \mathrm{~b} \\
\mathrm{~K} 82
\end{array}\right)>\left(\begin{array}{c}
\mathbf{S} 8 \\
\mathrm{~K} 78>\left(\begin{array}{c}
\mathrm{K} 35 \\
\mathrm{~K} 35 \mathrm{~b}
\end{array}\right)
\end{array}\right)>\mathrm{K} 16 \mathrm{~b}>\mathrm{K} 76>\left(\begin{array}{c}
\mathrm{K} 111 \\
\mathrm{~K} 13 \mathrm{a} \\
\mathrm{K} 13 \mathrm{~b}
\end{array}\right) \approx \mathrm{S} 7,
\end{gathered}
$$

where parenthesized groups represent phases (unordered sets of dates) and the $\approx$ symbol denotes similar ages. As noted earlier, we interpret $\mathbf{S 7}$ to be roughly coeval with layer L19b, where samples K111, K13a, and K13a were collected. Similarly, the stratigraphic position of sample K93 corresponds roughly to that of the S12 horizon. In the absence of an older sample that would allow for a more robust dating of S12, we use the age of $\mathrm{K} 93$ as our best estimate of the timing of $\mathrm{S} 12$. The corresponding OxCal model is displayed in Figure 11 , and resulting age bounds are reported in Table 5 .

Finally, the S13 horizon lies more than $1 \mathrm{~m}$ below the oldest dated sample, K93, and as a result its timing can only be constrained to be significantly older than $\sim 12 \mathrm{ka}$.

\section{Discussion}

Paleoclimatic Interpretation

The age-vs.-depth calibration of the Kazzâb sediments (Fig. 6) supports the inference that first-order stratigraphic divisions of the lacustrine sequence reflect regional climatic change. The fact that the clay/marl transition is a lakewide feature, systematically observed not only in the Kazzâb trench, but also in other trenches not discussed here, implies that it reflects external environmental forcing. The age of 
OxCal v4beta3 Bronk Ramsey (2006); r:5 IntCal04 atmospheric curve (Reimer et al 2004)

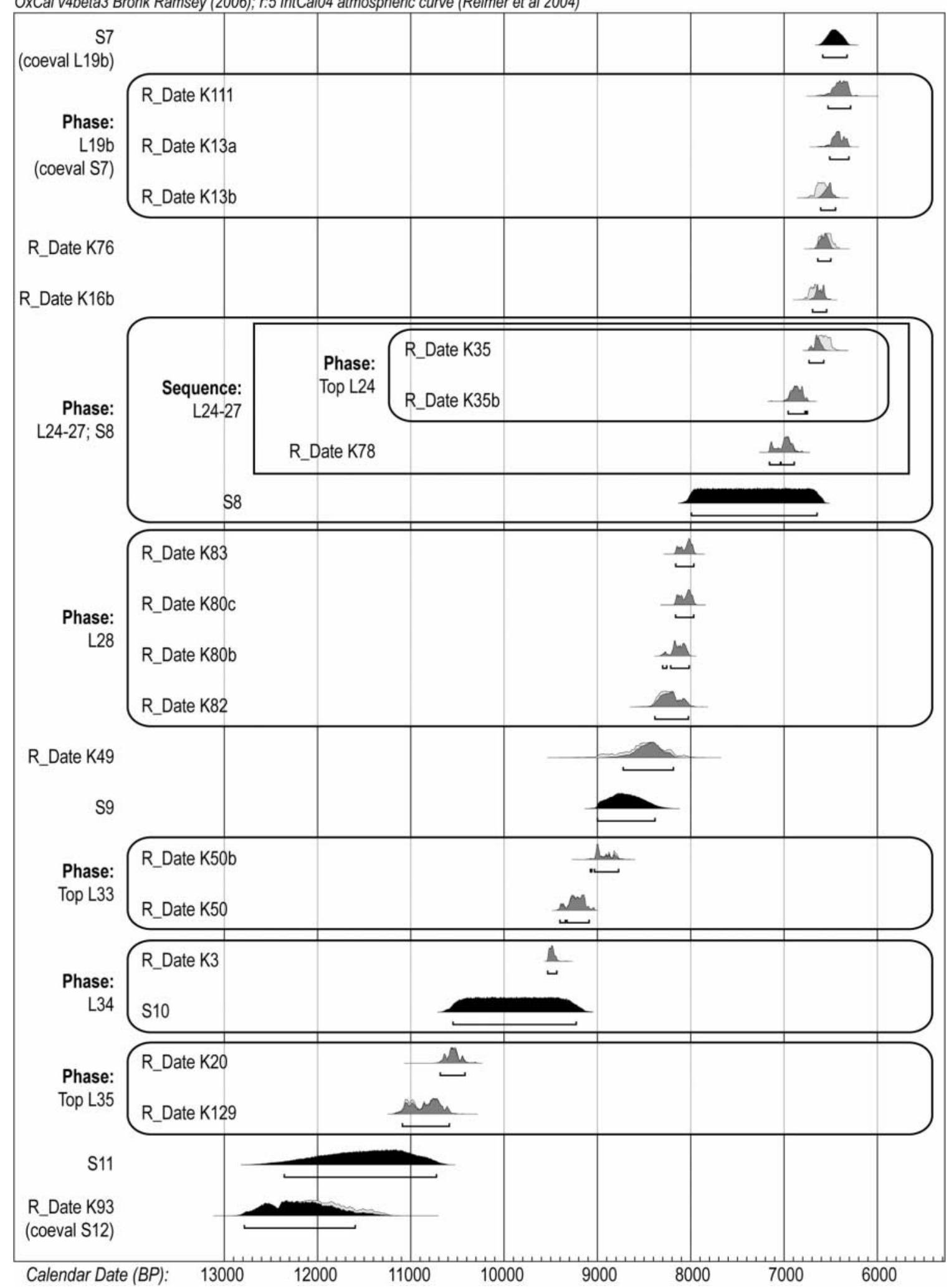

Figure 11. "Prehistoric" series of events. Time probability distributions (TPDs) in light gray are calibrated using terrestrial curve IntCal04 (Reimer et al., 2005). Darkgray TPDs are modeled using OxCal $4 \beta 3$ (Bronk Ramsey, 1995, 2001), according to the Bayesian model discussed in the text, with subsequences displayed as rectangles, and phases (unordered groups) as rounded boxes. The resulting TPDs of events S7-12 are plotted in black. Horizontal bars correspond to $95.4 \%$ confidence limits. 
this transition can be estimated by interpolating between the ages of K129 and K93, which yields a date of 11,271 \pm 400 cal yr B.P., coeval with the $\sim 11.5$-ka end of the Younger Dryas, as recorded by speleothems in the Soreq Cave, $300 \mathrm{~km}$ south of Yammoûneh (Bar-Matthews et al., 2003).

Similarly, the marls of sequence III form a distinctive, 1-m-thick package of thick beds (L22-30), whose ages range from $8692 \pm 309$ to $6550 \pm 102 \mathrm{cal}$ yr B.P. Again, this closely fits the bounds of the Early Holocene Climatic Optimum, constrained by the Soreq data to the period between 8.5 and $7 \mathrm{ka}$ (Bar-Matthews et al., 2003). The alternating light and dark beige beds within this Early Holocene marl sequence may reflect roughly bicentennial cycles linked to solar forcing, as detected during MIS 2 in the Lisan lake beds by Prasad et al. (2004).

More specific interpretations in terms of past climates will require a thorough paleoclimatic study of the Yammoûneh sediments, currently underway. Preliminary sedimentological and palynological analyses suggest that the clays of sequences V-VII were deposited in an ephemeral swamp under relatively dry and cool conditions, and that the calcareous marls reflect wetter (and presumably warmer) conditions (F. Gasse, personal comm., 2006).

Several factors might have triggered the sedimentary change from clays to marls. In the northern part of the basin, channel mapping based on surface shades in the fanglomerate infill show a south-diverging fan pattern, implying that the Aïnata river once filled the basin with a prograding delta. By contrast, calcareous marls are only observed in the southern third of the basin, in the area located directly between the Jabal Mnaïtra karstic springs, and the Jabal el-Qalaa sinkholes (Fig. 4). Such disparity suggests that the two types of sediments have different origins. The abrupt transition from clays to marls, around the end of the Younger Dryas, could have resulted from climate-driven damming of the Aïnata river by transverse debris-flow fans (Fig. 4a), greatly reducing the supply of clay-rich detrital sediments.

Preliminary investigation from a nearby trench reveals that the Holocene marls comprise mostly authigenic carbonate (F. Gasse, personal comm., 2006). The dearth of detrital material suggests that the supply by local runoff was then small, in keeping with the modern basin's limited watershed and with the predominantly karstic origin of its water.

A purely paleoclimatic interpretation of some of the dark horizons that stand out in the uppermost light-colored marls is less straightforward. L7a, which is particularly dark in the central section of wall $\mathrm{K}$, tapers and lightens away from the fault zone. L19/21, at the base of sequence II, is thickest in a sag located $1 \mathrm{~m}$ east of the fault and tapers eastward. Such horizons appear to be related to ground deformation in the fault zone, due to ponding resulting from coseismic warping of the underlying layers, and therefore may be unrelated to regional climate.

Finally, regional paleoclimate records offer insight into the paleoenvironment of sequence II. There is reliable evidence for a regional episode of great aridity circa $4 \mathrm{ka}$ (e.g.,
Cullen et al., 2000), which correlates with the largest Holocene drops in the level of the Dead Sea (e.g., Klinger et al., 2003; Bookman et al., 2004) and of Lake Tiberias (e.g., Hazan et al., 2005). An arid paleoenvironment at Yammoûneh around $4 \mathrm{ka}$ would be consistent with partial erosion of sequence II, either due to meandering channels in a lowwater setting or to eolian erosion of the dried-up lake. It might also account, in part, for the lack of organic material in sequence II.

\section{Historical Identification of Events}

Overall, the Kazzâb record displays evidence for at least 10 and at most 13 paleoearthquakes, over a period extending back more than $12 \mathrm{kyr}$. Within this time span, we have good time constraints on two plurimillennial intervals, a "historical" sequence from $2025 \pm 100$ cal yr B.P. to the earlytwentieth century, and a "prehistoric" sequence from 12,047 \pm 658 to $6445 \pm 121$ cal yr B.P.

The occurrence of the latest event recorded at this site, S1, is constrained to the tenth to fourteenth centuries A.D. (Fig. 10). During that interval, the most prominent regional historical earthquake was the $M_{S} \sim 7.6$, A.D. 1202 event (Table 2). Its area of strongest damage was centered around the Beqaa (Ambraseys and Melville, 1988) and it is known to have offset the walls of a Crusader fortification by $1.6 \mathrm{~m}$ (Ellenblum et al., 1998), just south of the Lebanese restraining bend ("Vadum Jacob," Fig. 1b). Although other, smaller events have been reported locally in the area of the restraining bend during that period-A.D. 991, near Damascus and Baalbek; A.D. 1063, near Tripoli; Abou Karaki (1987); BenMenahem (1991); Guidoboni et al. (1994)—, their strongest effects were reported tens of kilometers away from the Yammoûneh fault, which points to other active faults as the sources of these events. Our data thus imply that $\mathrm{S} 1$ was the 1202 earthquake, in keeping with previous historical inferences. For a more detailed discussion of this event, including qualitative geomorphic evidence and a reinterpretation of historical reports, see Daëron et al. (2005).

As noted previously, we favor the interpretation that the breaks tentatively attributed to ?S2 were in fact produced by S1. The large estimated magnitude of the A.D. 1202 earthquake is consistent with a zone of surface deformation ("mole tracks") broader than the single, localized break F1 (Figs. 7, 8, and Plate 1). If ?S2 were a distinct event, it would have occurred between A.D. 405 and 945 (Fig. 10). One might be rempted to correlate it with the historical A.D. 551 earthquake (Table 2), but support is growing for the offshore Mount Lebanon thrust system to be the source of this event (Elias, 2006; Morhange et al., 2006; Elias et al., 2007). Thus we conclude that if an earthquake did occur between A.D. 405 and 945 on the Yammoûneh fault, the historical record fails to provide an obvious corresponding event.

The occurrence of $\mathrm{S} 3$ is constrained from 30 B.C. to A.D. 469 (Fig. 10). This event might correspond to a poorly documented earthquake reported to have damaged Beirut in 
A.D. 348/349 (Plassard, 1968; Abou Karaki, 1987; BenMenahem, 1991; Guidoboni et al., 1994). Roman temples within $\sim 10 \mathrm{~km}$ of the Yammoûneh fault (Niha, Afqa) show evidence of strong shaking such as toppled walls and columns, although the date of the corresponding destructive events remains unknown. A mid-fourth century earthquake might also account for the sudden termination of construction work on the Baalbek temples, more conventionally interpreted as a result of the Roman empire's official conversion to Christianity (Alouf, 1998; Jidejian, 1998).

The overall interpretation of the S1-3 "historical" sequence depends on whether ?S2 is distinct from S1. If it is not, the two latest earthquakes were S1 (A.D. 1202) and S3 (30 B.C. to A.D. 469), and the corresponding interseismic period lasted 733-1230 yr (Fig. 12). If, on the other hand, ?S2 was a distinct event, the "historical" mean return time of would be only half as long (366-615 yr).

\section{Prehistoric Sequence of Events}

The stratigraphic units which record the prehistoric sequence of events (S7-12) are among the most distinctive, with many unambiguous and continuous markers and no evidence of a sedimentary gap. It is thus likely that this sequence represents a locally complete record of paleoearthquakes. $5635 \pm 675 \mathrm{yr}$ elapsed between S12 and S7, which yields a mean return time (MRT) of $1127 \pm 135 \mathrm{yr}$ during this period (Fig. 12). We must stress that the error bar of this value reflects the uncertainty in the dating of S7 and S12, rather than the statistical variance in the successive interseismic intervals. Unfortunately, the available constraints on individual events are too broad to address the issue of the regularity or irregularity of earthquake occurrence at this site.

Reassessment of Seismic Hazard Related to the Yammoûneh Fault

The time probability distribution of the "long-term" MRT from $\sim 12 \mathrm{ka}$ to $\sim 6.4 \mathrm{ka}$ is not statistically different from that of the time elapsed between S3 and S1 (Fig. 12), which suggests that the average frequency of events might not have varied significantly since $\sim 6.4 \mathrm{ka}$. If indeed this is the case, previous assessments of seismic hazard in the Lebanese restraining bend would need to be radically revised. In general, it has been inferred that the Yammoûneh fault was the source of both the May 1202 and November 1759 events (e.g., Ambraseys and Barazangi, 1989), which implies a return time on the order of $560 \mathrm{yr}$ (e.g., Harajli et al., 2002). The Yammoûneh fault would thus presently be far from the end of its seismic cycle.

Instead, our results establish that the 1202 event was the last one to rupture the fault (Daëron et al., 2005). In Figure 12 we compare the $804 \mathrm{yr}$ elapsed since A.D. 1202 with the time probability distribution of six of the intervals elapsed between the Kazzâb events, and with the "prehistoric" MRT.

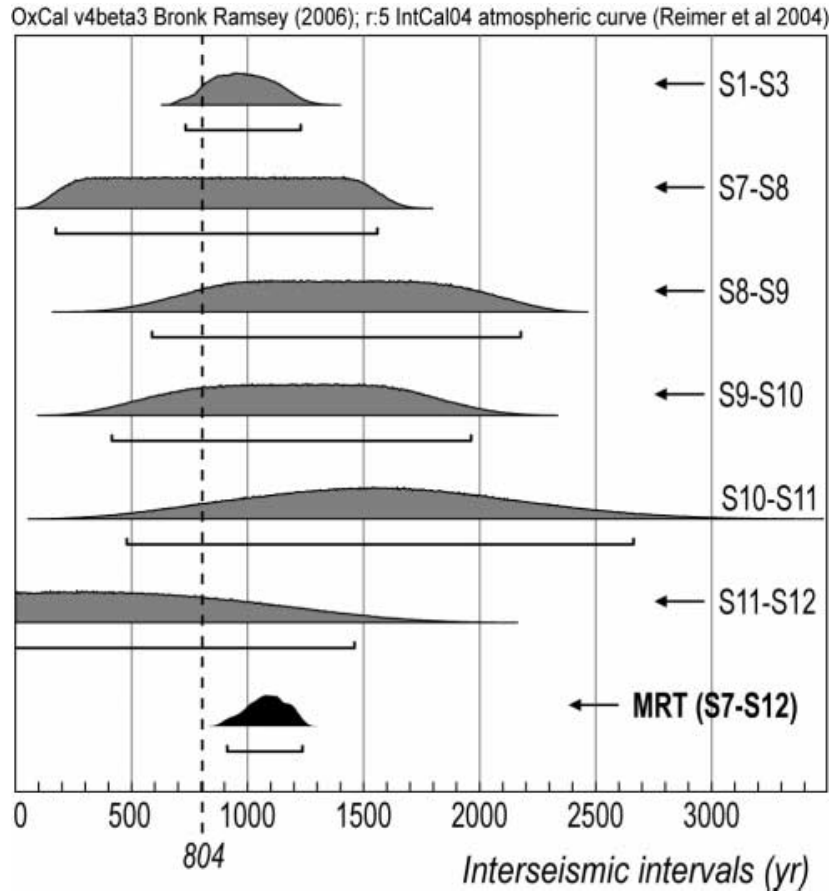

Figure 12. Seismic return intervals. Time probability distributions (TPDs) of the various intervals elapsed between consecutive events in the Kazzâb record are plotted in gray. The narrower, black TPD is that of the mean return time at this site between $\sim 12$ and $\sim 6.4 \mathrm{ka}$. The uncertainty on this mean return time does not reflect variability in the length of individual seismic cycles. Horizontal bars correspond to $95.4 \%$ confidence limits. Dashed line indicates the 804 yr currently elapsed since the latest event (A.D. 1202).

Such a span of eight centuries is statistically similar to all individual intervals, including the most tightly constrained one, between S3 and S1. Although 804 yr lie outside the error bar of the "prehistoric" mean return time, this does not imply that an earthquake is unlikely to occur in the coming $\sim 100 \mathrm{yr}$, because, as noted previously, this MRT error bar tells us nothing about the variability of individual seismic cycle durations.

Based on the average $\sim 1100$-yr-long loading time of the Yammoûneh fault and on the postglacial slip rate ( $\sim 5 \mathrm{~mm} / \mathrm{yr}$ ), estimated from the offsets of ${ }^{36} \mathrm{Cl}$-dated fans (Daëron et al., 2004), a characteristic coseismic slip on the order of $5.5 \mathrm{~m}$ is expected. Using macroseismic scaling laws (Wells and Coppersmith, 1994; Ambraseys and Jackson, 1998), this would correspond to magnitudes of 7.3-7.5, similar to estimates derived from historical reports for the A.D. 1202 event (Table 2). Assuming a slip-predictable fault behavior, if an earthquake occurred today it would still be expected to produce a magnitude larger than 7 . Were it to occur, such an event would likely have a devastating impact on the whole of Lebanon, whose territory lies entirely within $30 \mathrm{~km}$ of the Yammoûneh fault. The seismic hazard from 
this fault thus presents an immediate safety concern which should be rapidly addressed, at a time when many Lebanese population centers are being rebuilt.

Regional Seismic Hazard from Paleoand Historical Seismicity

How does the Kazzâb record compare with historical, archaeological and paleoseismic data from adjacent strands of the Levant fault? In the southern Zebadani valley (Fig. 1b), Gomez et al. (2003) have documented the paleoseismic record of the Serghaya fault since $6.5 \mathrm{ka}$. They identified five events, the latest having occurred in the eighteenth century (Fig. 13). It is extremely likely that this eighteenth century event is the $M_{\mathrm{S}} \sim 7.4$ earthquake of November 1759 (Table 2), as discussed by Daëron et al. (2005) based on the combined assessment of historical sources, geomorphic observations, and the paleoseismic data detailed here. All the older Zebadani events occurred during the poorly constrained interval of the Kazzâb record (2.0-6.4 ka). The corresponding MRT was $\sim 1300 \mathrm{yr}$, with average coseismic slip amounts of $\sim 2 \mathrm{~m}$.

For now, unfortunately, it is difficult to compare these two data sets, although testing the time correlation of large events on these two parallel strike-slip faults, which lie only 25-30 km apart, would be of great interest. Because of elastic interaction, coseismic slip on one of these faults is expected to significantly unload the other, providing a good opportunity to document short-range fault interaction from combined paleoseismic records. For instance, one might speculate that the occurrence of the 1202 event is responsible for the longer than average quiescence period prior to 1759 on the Serghaya fault ( $1800 \mathrm{yr}$ versus $1300 \mathrm{yr})$.
On the Yammoûneh fault, slip appears to be released in slightly more frequent and significantly larger earthquakes ( $\sim 5.5 \mathrm{~m}$ every $\sim 1100 \mathrm{yr}$ on average). This suggests that the similar mean return times on the two faults are driven by regional stress loading, whereas the size of individual earthquakes is more directly related to fault geometry, in particular, segment length. The faster slip rate on the Yammoûneh fault $(5.1 \pm 1.3 \mathrm{~mm} / \mathrm{yr})$ than on the Serghaya fault $(1.4 \pm$ $0.2 \mathrm{~mm} / \mathrm{yr}$ [Gomez et al., 2003]) might thus primarily result from a longer seismic rupture length $(\sim 190 \mathrm{~km}$ versus $\sim 115 \mathrm{~km}$ ).

North of the restraining bend, Meghraoui et al. (2003) have described evidence for the last three events on the Missyaf segment of the Ghab fault, in Western Syria (Fig. 1). The latest one is the large A.D. 1170 earthquake, historically well described by Guidoboni et al. (2004). The two preceding events occurred around A.D. 100-450 (event X) and A.D. 700-1030 (event Y). South of the restraining bend, many studies suggest that the Jordan Valley fault system (Fig. 1) slipped during the earthquakes of 31 B.C., A.D. 363, 749, 1033, and 1546 (Reches and Hoexter, 1981; Abou Karaki, 1987; Ben-Menahem, 1991; Ambraseys and Karcz, 1992; Ambraseys et al., 1994; Guidoboni et al., 1994; Marco et al., 2003). Figure 13 summarizes these records along with the most recent Kazzâb events.

The only well-dated medieval earthquakes on the Yammoûneh and Ghab faults took place during a period of unusually high seismic activity along the Levant fault, spanning the eleventh and twelfth centuries. From A.D. 1033 to 1202 , it appears that the whole length of the fault system slipped in a series of at least five $M>7$ events (e.g., BenMenahem, 1991; Ambraseys et al., 1994; Guidoboni et al., 1994). The records of the North Anatolian and Kunlun fault

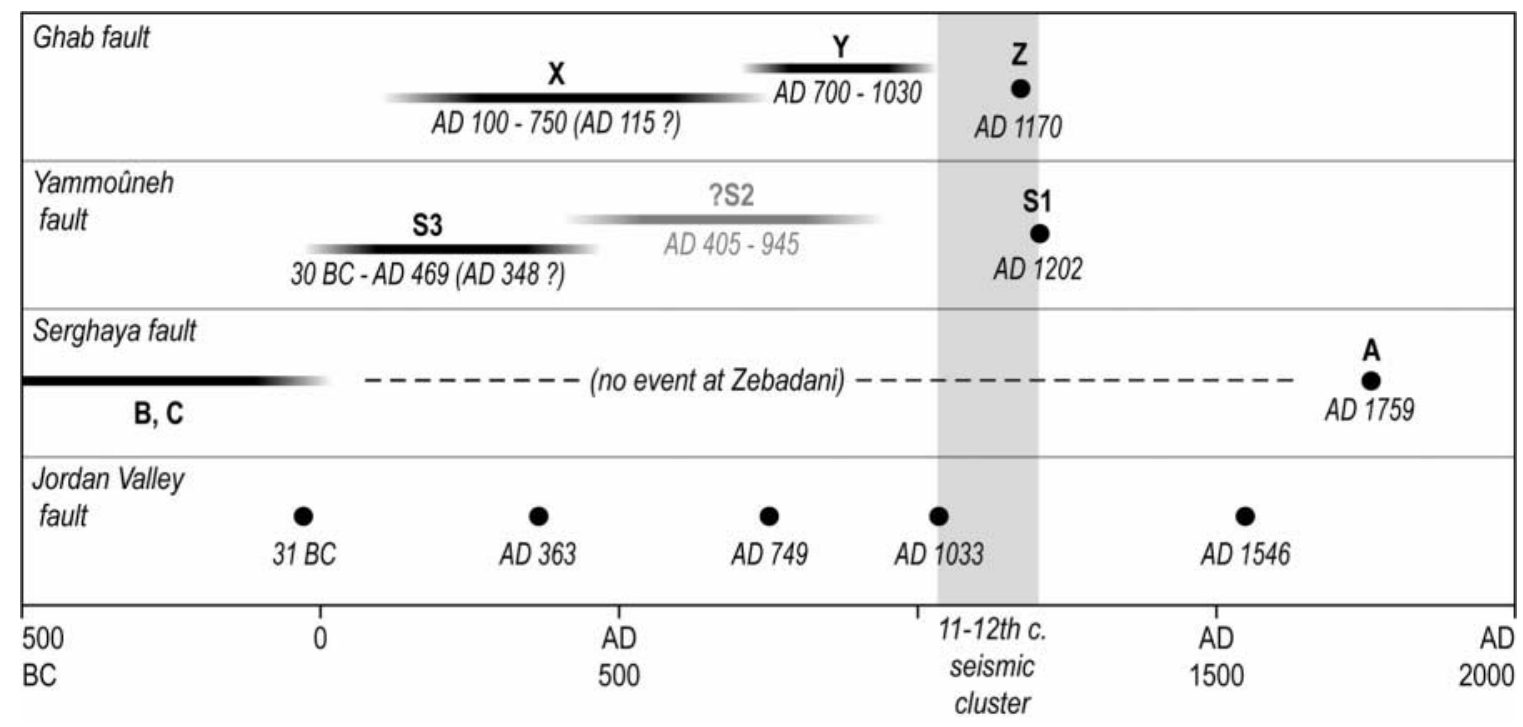

Figure 13. Compared paleoseismic records of faults in the LRB area, based on data from this study, Reches and Hoexter (1981), Gomez et al. (2003), Marco et al. (2003), Meghraoui et al. (2003), and historical catalogs (references in text). 
systems (e.g. Ambraseys and Melville, 1982; Van der Woerd et al., 2002), which typically release strain during $\sim 100-\mathrm{yr}-$ long sequences of large earthquakes, suggest that this behavior might be characteristic of strike-slip systems at this scale. If this were the case, the large $\left(M_{\mathrm{W}} \sim 7.3\right)$ earthquake that ruptured the southernmost section of the Levant fault system in A.D. 1995 might herald such a centennial sequence, contrasting with the relative quiescence of twentieth century Levantine seismicity.

Testing this hypothesis will require tighter age constraints on early medieval and older events on the Yammoûneh and Ghab faults. For instance, if event S3 in the Kazzâb record were indeed the mid-fourth-century earthquake that damaged Beirut, it could be correlated with the well-known A.D. 363 earthquake on the Jordan Valley fault (BenMenahem, 1991; Guidoboni et al., 1994). Moreover, the exact sources of these ancient events must be systematically sorted out, taking into account the surface complexity of the fault system. Resolving these issues requires combining paleoseismic and archaeological data to reach beyond the scope of this study. The Levant area, with its exceptional historical and archaeological records, in a mostly arid environment, offers a unique opportunity to document the behavior of fault systems at millennial timescales.

\section{Acknowledgments}

Many thanks to everyone at the National Center for Geophysical Research in Bhannes, Lebanon, for their invaluable help in the field. This work has been supported by the National Council for Scientific Research of Lebanon, the Institut National des Sciences de l'Univers of France, and the French Ministère des Affaires Etrangères. Additional funding was provided by the Institut de Physique du Globe de Paris. We wish to thank NCSR General Secretary M. Hamze, for his long-term support; G. Seitz and M. Kashgarian, for help and advice about radiocarbon sample processing and AMS; and F. Gasse, for sharing her early paleoclimatic and palynological results. This article benefitted greatly from thorough reviews by T. Niemi and G. Biasi. This is Institut de Physique du Globe de Paris contribution no. 2190.

\section{References}

Abou Karaki, N. (1987). Synthèse et carte sismotectonique des pays de la bordure orientale de la Méditerranée: sismicité du système de failles du Jourdain-Mer Morte, Ph.D. Thesis, Université Louis Pasteur de Strasbourg.

Alouf, M. (1998). History of Baalbek, Book Tree, San Diego, California.

Al-Tarazi, E. (2000). The major Gulf of Aqaba earthquake, 22 November 1995-maximum intensity distribution, Nat. Hazards 22, 17-27.

Ambraseys, N., and M. Barazangi (1989). The 1759 earthquake in the Bekaa valley: implications for earthquake hazard assessment in the Eastern Mediterranean region, J. Geophys. Res. 94, no. B4, 4007-4013.

Ambraseys, N., and J. Jackson (1998). Faulting associated with historical and recent earthquakes in the Eastern Mediterranean region, Geophys. J. Int. 133, 390-406.

Ambraseys, N., and I. Karcz (1992). The earthquake of 1546 in the Holy Land, Terra Nova 4, no. 2, 254-263.

Ambraseys, N., and C. Melville (1982). A History of Persian Earthquakes, Cambridge University Press, New York.

Ambraseys, N., and C. Melville (1988). An analysis of the eastern Mediterranean earthquake of 20 May 1202, in History of Seismography and Earthquakes of the World, W. Lee, H. Meyers, and K. Shimazaki (Editors), Academic Press, San Diego, California, 181-200.

Ambraseys, N., C. Melville, and R. Adams (1994). The Seismicity of Egypt, Arabia and the Red Sea-A Historical Review, Cambridge University Press, New York.

Armijo, R., N. Pondard, B. Meyer, G. Ucarkus, B. de Lepinay, J. Malavieille, S. Dominguez, M. Gustcher, S. Schmidt, C. Beck, N. Cagatay, Z. Cakir, C. Imren, K. Eris, B. Natalin, S. Ozalaybey, L. Tolun, I. Lefevre, L. Seeber, L. Gasperini, C. Rangin, O. Emre, and K. Sarikavak (2005). Submarine fault scarps in the Sea of Marmara pullapart (North Anatolian Fault): implications for seismic hazard in Istanbul, Geochem. Geophys. Geosys. 6, Q06009.

Avni, R., D. Bowman, A. Shapira, and A. Nur (2002). Erroneous interpretation of historical documents related to the epicenter of the 1927 Jericho earthquake in the Holy Land, J. Seism. 6, 469-476.

Barka, A., and K. Kadinsky-Cade (1988). Strike-slip-fault geometry in Turkey and its influence on earthquake activity, Tectonics 7, no. 3, 663684.

Bar-Matthews, M., A. Ayalon, M. Gilmour, A. Matthews, and C. Hawkesworth (2003). Sea-land oxygen isotopic relationships from planktonic foraminifera and speleothems in the Eastern Mediterranean region and their implication for paleorainfall during interglacial intervals, Geochim. Cosmochim. Acta 67, no. 17, 3181-3199.

Ben-Menahem, A. (1991). Four thousand years of seismicity along the Dead Sea rift, J. Geophys. Res. 96, no. B12, 20,195-20,216.

Ben-Menahem, A., and E. Aboodi (1981). Micro- and macro-seismicity of the dead sea rift and off-coast eastern mediterranean, Tectonophysics 80, no. 1-4, 199-233.

Besançon, J. (1968). Le poljé de Yammoûné, Hannon (Rev. Libanaise Géogr.) 3, 3-62.

Biasi, G., R. Weldon, T. Fumal, and G. Seitz (2002). Paleoseismic event dating and the conditional probability of large earthquakes on the southern San Andreas fault, California, Bull. Seism. Soc. Am. 92, no. 7, 2761-2781.

Bookman, R., Y. Enzel, A. Agnon, and M. Stein (2004). Late Holocene lake levels of the Dead Sea, Geol. Soc. Am. Bull. 116, no. 5-6, 555571.

Bosworth, W., P. Huchon, and K. McClay (2005). The Red Sea and Gulf of Aden basins, J. Afr. Earth Sci. 43, 334-378.

Bronk Ramsey, C. (1995). Radiocarbon calibration and analysis of stratigraphy: the OxCal program, Radiocarbon 37, no. 2, 425-430.

Bronk Ramsey, C. (2001). Development of the radiocarbon program OxCal, Radiocarbon 43, no. 2A, 355-363.

Carton, H. (2005). Etudes tectoniques en Mediterrannee orientale par analyse de donnees de sismique reflexion: Mer de Marmara (Bassin de Cinarcik) et marge du Liban, Ph.D. Thesis, Institut de Physique du Globe de Paris.

Chu, D., and R. Gordon (1998). Current plate motions across the Red Sea, Geophys. J. Int. 135, 313-328.

Courtillot, V., R. Armijo, and P. Tapponnier (1987). The Sinai triple junction revisited, Tectonophysics 141, 181-190.

Cullen, H., P. deMenocal, S. Hemming, G. Hemming, F. Brown, T. Guilderson, and F. Sirocko (2000). Climate change and the collapse of the Akkadian empire: evidence from the deep sea, Geology 28, no. 4, $379-382$.

Daëron, M. (2005). Rôle, cinématique et comportement sismique à long terme de la faille de Yammoûneh, principale branche décrochante du coude transpressif libanais, Ph.D. Thesis, Institut de Physique du Globe de Paris, www.daeron.fr (last accessed April 2007).

Daëron, M., L. Benedetti, P. Tapponnier, A. Sursock, and R. Finkel (2004). Constraints on the post $\sim 25$-ka slip rate of the Yammoûneh fault (Lebanon) using in situ cosmogenic ${ }^{36} \mathrm{Cl}$ dating of offset limestoneclast fans, Earth Planet. Sci. Lett. 227, 105-119.

Daëron, M., Y. Klinger, P. Tapponnier, A. Elias, E. Jacques, and A. Sursock (2005). Sources of the large A.D. 1202 and 1759 Near East earthquakes, Geology 33, no. 7, 529-532, doi 10.1130/G21352.1.

Darawcheh, R., M. Sbeinati, C. Margottini, and S. Paolini (2000). The 
9 July A.D. 551 Beirut earthquake, Eastern Mediterranean region, J. Earthquake Eng. 4, no. 4, 403-414.

Deng, Q., S. Chen, F. Song, S. Zhu, Y. Wang, W. Zhang, B. Burchfiel, P. Molnar, L. Royden, and P. Zhang (1986). Variations in the geometry and amount of slip on the Haiyuan fault zone, China and the surface rupture of the 1920 Haiyuan earthquake, Earthquake Source Mechanics, American Geophysical Monograph 3, 169-182.

Dubertret, L. (1975). Carte géologique du Liban au 1/50,000.

Elias, A. (2006). Le chevauchement de Tripoli-Saïda: Croissance du MontLiban et risque sismique, Ph.D. Thesis, Institut de Physique du Globe de Paris.

Elias, A., P. Tapponnier, S. C. Singh, G.C.P. King, A. Briais, M. Daëron, H. Carton, A. Sursock, E. Jacques, R. Jomaa, and Y. Klinger (2007). Active thrusting offshore Mount Lebanon: Source of the tsunamigenic A.D. 551 Beirut-Tripoli earthquake, Geology (in press).

Ellenblum, R., S. Marco, A. Agnon, T. Rockwell, and A. Boas (1998). Crusader castle torn apart by earthquake at dawn, 20 May 1202, Geology 26, 303-306.

Ö. Emre, Y. Awata, and T. Duman (Editors) (2003). Surface Rupture Associated with the August 17, 1999 Izmit Earthquake, Vol. 1, Special publication series, MTA Ankara.

Freund, R., Z. Garfunkel, I. Zak, I. Goldberg, T. Weisbrod, and B. Derin (1970). The shear along the Dead Sea rift, Philos. Trans. R. Soc. Lond. 267, 107-130.

Garfunkel, Z., I. Zak, and R. Freund (1981). Active faulting in the Dead Sea rift, Tectonophysics 80, 1-26.

Gomez, F., M. Meghraoui, A. Darkal, F. Hijazi, M. Mouty, Y. Souleiman, R. Sbeinati, R. Darawcheh, R. Al-Ghazzi, and M. Barazangi (2003). Holocene faulting and earthquake recurrence along the Serghaya branch of the Dead Sea fault system in Syria and Lebanon, Geophys. J. Int. 153, 658-674.

Guidoboni, E., and A. Comastri (2005). Catalogue of Earthquakes and Tsunamis in the Mediterranean Area from the 11th to 15th Century, Instituto Nazionale di Geofisica \& Volcanologia-Storia Geofisica Ambiente, Bologna.

Guidoboni, E., F. Bernardini, A. Comastri, and E. Boschi (2004). The large earthquake on 29 June 1170 (Syria, Lebanon, and central southern Turkey), J. Geophys. Res. 109, no. B07304.

Guidoboni, E., A. Comastri, and G. Traina (1994). Catalogue of Ancient Earthquakes in the Mediterranean Area up to the 10th Century, Instituto Nazionale di Geofisica.

Harajli, M., S. Sadek, and R. Asbahan (2002). Evaluation of the seismic hazard of Lebanon, J. Seism. 6, 257-277.

Hazan, N., M. Stein, A. Agnon, S. Marco, D. Nadel, J. Negendank, M. Schwab, and D. Neev (2005). The late quaternary limnological history of Lake Kinneret (Sea of Galilee), Israel, Quat. Res. 63, no. 1, 6077.

Hofstetter, A. (2003). Seismic observations of the 22/11/1995 Gulf of Aqaba earthquake sequence, Tectonophysics 369, 21-36.

Hubert-Ferrari, A., A. Barka, E. Jacques, S. Nalbant, B. Meyer, R. Armijo, P. Tapponnier, and G. King (2000). Seismic hazard in the Marmara Sea region following the 17 August 1999 Izmit earthquake, Nature 404, 269-273.

Jidejian, N. (1998). Baalbek-Héliopolis, "cité du soleil", Librairie Orientale, Beyrouth.

Jing, L., Y. Klinger, K. Sieh, C. Rubin, and G. Seitz (2006). Serial ruptures of the San Andreas fault, Carrizo Plain, California, revealed by threedimensional excavations, J. Geophys. Res. 111, no. B2, B02306.

Klinger, Y., J. Avouac, D. Bourlès, and N. Tisnerat (2003). Alluvial deposition and lake-level fluctuations forced by Late Quaternary climate change: the Dead Sea case example, Sediment. Geol. 162, no. 1-2, 119-139.

Klinger, Y., J.-P. Avouac, N. Abou Karaki, L. Dorbath, D. Bourlès, and J.-L. Reyss (2000a). Slip rate on the Dead Sea transform fault in northern Araba valley Jordan, Geophys. J. Int. 142, 755-768.

Klinger, Y., J.-P. Avouac, L. Dorbath, N. Abou Karaki, and N. Tisnerat (2000b). Sesimic behaviour of the Dead Sea fault along the Araba valley, Jordan, Geophys. J. Int. 142, 769-782.

Klinger, Y., L. Rivera, H. Haessler, and J.-C. Maurin (1999). Active faulting in the Gulf of Aqaba: New knowledge from the $\mathrm{M}_{\mathrm{W}} 7.3$ earthquake of 22 November 1995, Bull. Seism. Soc. Am. 89, no. 4, 10251036.

Klinger, Y., X. Xu, P. Tapponnier, J. Van der Woerd, C. Lasserre, and G. King (2005). High-resolution satellite imagery mapping of the surface rupture and slip distribution of the $M_{\mathrm{w}} \sim 7.8,14$ November 2001 Kokoxili earthquake, Kunlun fault, northern Tibet, China, Bull. Seism. Soc. Am. 95, no. 5, 1970-1987.

Mahmoud, S., R. Reilinger, S. McClusky, P. Vernant, and A. Tealeb (2005). Gps evidence for northward motion of the Sinai Block: implications for E. Mediterranean tectonics, Earth Planet. Sci. Lett. 238, 217-224.

Manighetti, I., P. Tapponnier, P.-Y. Gillot, E. Jacques, V. Courtillot, R. Armijo, J.-C. Ruegg, and G. King (1998). Propagation of rifting along the Arabia-Somalia plate boundary: Into Afar, J. Geophys. Res. 103, no. B3, 4947-4974.

Marco, S., M. Hartal, N. Hazan, L. Lev, and M. Stein (2003). Archaeology, history and geology of the a.d. 749 earthquake, Dead Sea transform, Geology 31, 665-668.

Marco, S., T. Rockwell, A. Heimann, U. Frieslander, and A. Agnon (2005). Late Holocene activity of the Dead Sea Transform revealed in 3D palaeoseismic trenches on the Jordan Gorge segment, Earth Planet. Sci. Lett. 234, no. 1-2, 189-205.

McClusky, S., R. Reilinger, S. Mahmoud, D. Ben Sari, and A. Tealeb (2003). GPS constraints on Africa (Nubia) and Arabia plate motions, Geophys. J. Int. 155, 126-138.

McKenzie, D., D. Davies, and P. Molnar (1970). Plate tectonics of the Red Sea and East Africa, Nature 226, no. 5242, 243-248.

Meghraoui, M., F. Gomez, R. Sbeinati, J. Van der Woerd, M. Mouty, A. Darkal, Y. Radwan, I. Layyous, H. Al Najjar, R. Darawcheh, F. Hijazi, R. Al-Ghazzi, and M. Barazangi (2003). Evidence for 830 years of seismic quiescence from palaeoseismology, archaeology and historical seismicity along the Dead Sea fault in Syria, Earth Planet. Sci. Lett. 210, 35-52.

Morhange, C., P. Pirazzoli, N. Marriner, L. Montaggioni, and T. Nammour (2006). Late Holocene relative sea-level changes in Lebanon, Eastern Mediterranean, Mar. Geol. 230, no. 1-2, 99-114.

Niemi, T., H. Zhang, M. Atallah, and J. Harrison (2001). Late Pleistocene and Holocene slip rate of the Northern Wadi Araba fault, Dead Sea Transform, Jordan, J. Seism. 5, no. 3, 449-474.

Pelzer, G., P. Tapponnier, and R. Armijo (1989). Magnitude of Late Quaternary left-ateral displacements along the North edge of Tibet, Science 246, 1285-1289.

Plassard, J. (1956). Annales Séismologiques de l'observatoire de Ksara (Beirut).

Plassard, J. (1968). Crise séismique au Liban du IVe au VIe siècel, Mélanges de l'Université Saint-Joseph 44, no. 2, 9-20.

Poirier, J., and M. Taher (1980). Historical seismicity in the Near and Middle East, North Africa, and Spain from Arabic documents (VIIthXVIIIth century), Bull. Seism. Soc. Am. 70, no. 6, 2185-2201.

Prasad, S., H. Vos, J. Negendank, N. Waldmann, S. Goldstein, and M. Stein (2004). Evidence from Lake Lisan of solar influence on decadal- to centennial-scale climate variability during marine oxygen isotope stage 2, Geology 32, no. 7, 581-584, doi 10.1130/G20553.1.

Quennell, A. (1959). Tectonics of the Dead Sea rift, in Proceedings of the 20th International Geological Congress, Mexico, 385-403.

Reches, Z., and D. Hoexter (1981). Holocene seismic and tectonic activity in the Dead Sea area, Tectonophysics 80, 235-254.

Reimer, P. J., M. G. Baillie, E. Bard, A. Bayliss, W. W. Beck, C. J. Bertrand, P. G. Blackwell, C. E. Buck, G. S. Burr, K. B. Cutler, P. E. Damon, L. L. Edwards, R. G. Fairbanks, M. Friedrich, T. P. Guilderson, A. G. Hogg, K. A. Hughen, B. Kromer, G. Mccormac, S. Manning, C. B. Ramsey, R. W. Reimer, S. Remmele, J. R. Southon, M. Stuiver, S. Talamo, F. Taylor, J. v. d. van der Plicht, and C. E. Wey- 
henmeyer (2005). IntCal04 terrestrial radiocarbon age calibration, 026 cal kyr BP, Radiocarbon 46, no. 3, 1029-1058.

Service météorologique du Liban (1971). Atlas climatique du Liban, Beirut, Lebanon.

Sieh, K. (1984). Lateral offsets and revised dates of large prehistoric earthquakes at Pallett Creek, Southern California, J. Geophys. Res. 89, no. B9, 7641-7670.

Stein, R. S., A. A. Barka, and J. Dieterich (1997). Progressive failure on the North Anatolian fault since 1939 by earthquake stress triggering, Geophys. J. Int. 128, no. 3, 594-604.

Van der Woerd, J., P. Tapponnier, F. Ryerson, A.-S. Mériaux, B. Meyer, Y. Gaudemer, R. Finkel, M. Caffee, Z. Guoguang, and X. Zhiqin (2002). Uniform postglacial slip-rate along the central $600 \mathrm{~km}$ of the Kunlun Fault (Tibet), from ${ }^{26} \mathrm{Al},{ }^{10} \mathrm{Be}$, and ${ }^{14} \mathrm{C}$ dating of riser offsets, and climatic origin of the regional morphology, Geophys. J. Int. 148, 356-388.

Wdowinski, S., Y. Bock, G. Baer, L. Prawirodirdjo, S. Bechor, S. Naaman, R. Knafo, Y. Forrai, and Y. Melzer (2004). GPS measurements of current crustal movements along the Dead Sea Fault, J. Geophys. Res. 109, 305403.

Weldon, R., T. Fumal, and G. Biasi (2004). Wrightwood and the earthquake cycle: what a long recurrence record tells us about how faults work, Geol. Soc. Am. Today 14, no. 9, 4-10.
Wells, D., and K. Coppersmith (1994). New empirical relationships among magnitude, rupture length, rupture width, rupture area, and surface displacement, Bull. Seism. Soc. Am. 84, 974-1002.

Institut de Physique du Globe de Paris

75005 Paris, France

daeron@gps.caltech.edu

klinger@ipgp.jussieu.fr

tappon@ipgp.jussieu.fr

elias@ipgp.jussieu.fr

jacques@ipgp.jussieu.fr

(M.D., Y.K., P.T., A.E., E.J.)

National Council for Scientific Research

11072260 Beirut, Lebanon

asursock@cnrs.edu.lb

(A.E., A.S.) 